\title{
Instruments for assessing nurses' palliative care knowledge and skills in specialised care setting: an integrative review.
}

SOIKKELI-JALONEN, A., STOLT, M., HUPLI, M., LEMETTI, T., KENNEDY, C., KYDD, A. and HAAVISTO, E.

This is the peer reviewed version of the following article: SOIKKELI-JALONEN, A., STOLT, M., HUPLI, M., LEMETTI, T., KENNEDY, C., KYDD, A. and HAAVISTO, E. 2020. Instruments for assessing nurses' palliative care knowledge and skills in specialised care setting: an integrative review. Journal of clinical nursing, 29(5-6), pages 736-757, which has been published in final form at https://doi.org/10.1111/jocn.15146. This article may be used for non-commercial purposes in accordance with Wiley Terms and Conditions for Use of Self-Archived Versions. 
Instruments for assessing nurses' palliative care knowledge and skills in specialised care setting: an integrative review.

\section{Concise title: Nurses' palliative care knowledge and skills}

\section{Authors:}

Anu Soikkeli-Jalonen, MA, RN, BNSc, MNSc student, Department of Nursing Science, University of Turku, Finland

Minna Stolt, $\mathrm{PhD}$, docent, university lecturer, Department of Nursing Science, University of Turku, Finland and researcher, Turku University Hospital, Finland Maija Hupli, RN, PhD, university lecturer, Department of Nursing Science, University of Turku, Finland

Terhi Lemetti, RN, MNSc, PhD Candidate, Clinical Nurse Specialist, Department of Nursing Science, University of Turku, Helsinki University Hospital, Finland

Catriona Kennedy PhD, BA(Hons), Dip Nurs., RN, DN, RNT, DNT, PWT, QNIS Professor of Community Nursing, School of Nursing and Midwifery, Robert Gordon University Aberdeen, UK, Adjunct Professor, Department of Nursing and Midwifery, The University of Limerick, Ireland

Angela Kydd, Clinical Professor in Nursing, School of Nursing and Midwifery, Robert Gordon University, Aberdeen, UK

Elina Haavisto, RN, Professor, Department of Nursing Science, University of Turku, Satakunta Central Hospital, Pori; Finland, elina.haavisto@utu.fi

\section{Correspondence:}

Anu Soikkeli-Jalonen, MA, RN, BNSc, MNSc student, Department of Nursing Science, FI20014, University of Turku, Finland.

E-mail: apsoik@utu.fi

Funding: The review was funded by Government research funding (Satakunta Hospital

District)

Conflict of Interest Statement: No conflict of interest has been declared by the authors.

\section{Contributions:}

Study conception and design: EH, MS, AS-J

Data collection: AS-J, EH

Quality appraisal: AS-J, TL, EH, MH

Data analysis and interpretation: AS-J, EH, MH

Drafting of the article: AS-J, EH, MH, MS, CK, TL, AK

Critical revision of the article: AS-J, EH, MH, MS, TL, CK, AK 


\title{
Instruments for assessing nurses' palliative care knowledge and skills in specialised care
} setting: an integrative review.

\section{Concise title: Nurses' palliative care knowledge and skills}

\begin{abstract}
Aims and objectives: To examine the content and reported psychometric properties of instruments for assessing nurses' palliative care knowledge and skills in specialised healthcare units.

Background: Knowledge of palliative care, and competence in the delivery of care, are essential. Assessment of competence is an important means of evaluating the knowledge and skills of practitioners in order to improve the quality of care provided for patients and their families. Design: An integrative review.

Methods: A systematic literature search was conducted in November 2018 in five databases: CINAHL, PubMed (Medline), Cochrane, Scopus and Web of Science. The quality assessment was conducted using the Joanna Briggs Institute's (JBI) Checklist for Analytical Cross-Sectional Studies. The data was analysed using content analysis. PRISMA guidelines were followed to ensure explicit reporting.
\end{abstract}

Results: Overall, 5,413 studies were identified and 23 met the inclusion criteria. Nurses' knowledge and skills, as assessed by the instruments, were: 1) care for the patient, 2) care for the patient's family and 3) professional requirements. Ten instruments were identified assessing nurses' knowledge and skills through knowledge tests and skill-evaluation self-tests. The psychometric properties of the instruments were reported to varying degrees, mainly focusing on internal consistency and content validation.

Conclusions: Nurses' knowledge and skills were seen to contribute to the holistic care of the patient and his or her family, and the possession of adequate information and skills is essential when dealing with death and dying. The instruments are commonly available and potentially 
reliable, although reliability must be determined with caution, so validation studies in other cultures are recommended.

Relevance to clinical practice: These results could be utilised to improve the quality of palliative care by evaluating the knowledge and skills of nursing staff, or when considering the needs of palliative care education.

KEYWORDS: Palliative care, terminal care, nursing, instrument, psychometrics, knowledge, skills, assessing, integrative review.

\section{What does this paper contribute to the wider global clinical community?}

\section{Summary:}

- An assessment of proficiency is needed to enhance the quality of palliative care by identifying and improving palliative care nurses' expertise; however, such assessment requires valid and reliable instruments.

- Knowledge tests can be used to form an objective judgement of nurses' knowledge of palliative care, and self-evaluation tests can be used to assess nurses' self-perceived confidence in performing palliative care.

- The findings of this review can be utilised to enhance the quality of palliative care nursing by determining applicable instruments for assessing nurses' palliative care knowledge and skills, as well as developing nursing education and lifelong learning. 


\section{Introduction}

The World Health Organization (WHO) defines palliative care as 'an approach that improves the quality of life of patients and their families facing the problem associated with lifethreatening illness, through the prevention and relief of suffering by means of early identification and impeccable assessment and treatment of pain and other problems: physical, psychosocial and spiritual' (WHO, 2019). According to the European Association for Palliative Care (EAPC), all healthcare professionals should be able to provide appropriate palliative care and be able to meet the needs of patients and their relatives through palliative care treatment (Gamondi, Larkin, \& Payne, 2013). Nurses are vital to the delivery of palliative care and nurses' palliative care competence is essential for ensuring high-quality care. Consensus exists regarding the fact that a lack of experience, knowledge and education is a common obstacle to quality care (Ahmed et al., 2004; Espinosa, Young \& Walsh, 2008; Huijer, Abboud, \& Dimassi, 2009; Slatten, Fagerström, \& Hatlevik, 2010; White \& Coyne, 2011; Schulman-Green, Ercolano, Jeon, \& Dixon, 2012).

At a general level, competence in palliative care nursing can be defined as a combination of knowledge, skills and attitudes involving evidence-based physical, emotional, psychosocial and spiritual care (Sherman, Matzo \& Metheny, 2010). In many countries, such as Great Britain, New Zealand, the USA, Canada, and Ireland, defined frameworks detail the areas of competence for palliative care (Connolly, Charnlay \& Reagan, 2012; Connolly, Ryan \& Charnlay, 2016). For example, the core areas of palliative care as defined by the US National Consensus Project for Quality Palliative Care include the structure and process of care, along with the physical, psychological, psychiatric, social, spiritual, religious and existential aspects of care. Cultural, ethical and legal factors are also important at the end of life (Ferrell, Twaddle, Melnick \& Meier, 2018). From a European perspective, the main competence areas reflect those identified above, although European guidelines also pay attention to the operating environment for patients and their families, 
implementing comprehensive cooperation and multi-professionalism, developing interaction skills, and identifying nurses' own skills and continuing professional development (Gamondi et al., 2013).

Knowledge of palliative care is essential in ensuring the delivery of professional care.

Globally, more than 40 million people annually need palliative care. Palliative care is an approach to care that is relevant to all long-term enduring illnesses and a range of conditions such as cardiovascular disease, cancer, chronic respiratory diseases, AIDS, diabetes and neurological conditions, including dementia. The need for palliative care is increasing as the population ages: the majority of patients requiring palliative care are over 60 years old (WCPA \& WHO, 2014) and the cost of end-of-life care is high (Haltia et al., 2018). It is accepted that the number of people over the age of 60 in the world population will almost double by 2050 (WHO, 2018). A similar phenomenon can also be seen in Europe, where the ageing population has been increasing for several decades and the number of people aged over 65 is expected to increase further (Eurostat, 2018).

The knowledge, skills and attitudes of healthcare professionals who provide care for the dying has a significant impact on what kind of care is delivered in practice (Harris, Gaudet \& O'Reardon, 2014). To ensure the quality of palliative care, healthcare professionals working in palliative care teams need to have a sufficient level of competence in palliative and end-of-life care (Hales, Zimmermann \& Rodin 2010; Miyashita, Sanjo, Morita, Hirai \& Uchitomi, 2007; SchulmanGreen et al., 2011; Weissman \& Blust, 2005). The self-assessment of competence has been shown to develop the palliative care skills of nurses and improve the quality of care (Desbiens, Gagnon \& Fillion, 2011). A range of measurement indicators have been used to assess nurses' competence in palliative care (Huijer et al., 2009; Bing-Jonsson et al., 2014; Mager \& Lang, 2016; Yaakup et al., 2014), however there is no consensus on the instruments for measuring nurses' palliative competence. 


\section{Aim}

The aim of this integrative literature review was to examine the content and reported psychometric properties of instruments used for assessing nurses' palliative care knowledge and skills in specialised care settings.

The review questions were:

1. What knowledge and skills of nursing staff is assessed in palliative care?

2. What instruments have been used to assess nurses' palliative care knowledge and skills?

3. What is the validity and reliability of the instruments used to assess palliative care knowledge and skills?

\section{Methods}

\subsection{Design}

An integrative review method was used to facilitate the inclusion of studies that used different research methodologies. This approach was considered to be applicable as it allows the combination of findings from several research designs. Integrative reviews are also relevant to the exploration of topics about which little is known and of relevance to practice (Whittemore \& Knafl, 2005). The review was conducted in line with the five stages specified by Whittemore and Knafl's (2005) integrative review methodology: 1) identification of the problem, 2) literature search, 3) data evaluation, 4) data analysis and 5) presentation of the results. The Preferred Reporting Items for Systematic Reviews and Meta-Analyses (PRISMA) guidelines for systematic literature reviews and meta-analyses were followed to ensure explicit reporting (Supplementary File 1).

\subsection{Search Strategy}

An integrative review was conducted in a systematic manner in November 2018 in the following databases: CINAHL, PubMed (Medline), Cochrane, Scopus and Web of Science. A health science reference librarian was consulted to ascertain and refine the validity of the search terms. The search consisted of the following keywords, their synonyms and MeSH-terms, using 
Boolean operators: 'palliative, hospice, terminal or end-of-life care, competence, knowledge, skill or ability' and 'nurse, healthcare personnel, healthcare staff, nursing staff or nursing personnel'. In addition, a manual search was conducted using a library database to ensure that all studies dealing with knowledge - or skill-measuring instruments were included. Although attitude is defined as one dimension of overall competence, the intention of this review was to particularly examine the nurses' knowledge and skills, rather than their attitudes towards their work in palliative care. Therefore, studies that used instruments to assess only attitudes were not included in this review.

Palliative care has received increasing attention during the 2000s. It has been recognized as part of essential health care by many international organizations such as the European Committee of Ministers, the WPCA, and Human Rights Watch (WPCA \& WHO, 2014). A search and analysis of research that has been carried out within last ten years was judged to be relevant given the growth in development of instruments focussed on palliative care over this timeframe. The search was limited to studies published with an available abstract between 1 January 2008 and 31 October 2018. The inclusion criteria specified that a study must: 1) include an instrument for assessing skills and knowledge, 2) apply the assessment to nursing professionals, 3) use a sample of nursing professionals working with adult palliative care patients in specialised care settings and 4) be scientific and peer-reviewed empirical study.

The criteria for exclusion were studies that: 1) examined other types of healthcare professionals or nursing students, 2) concerned only paediatric nursing or 3) did not include an instrument used for assessing knowledge or skills, 4) concerned practice in primary care, nursing homes, geriatric or older people care units or 5) were dissertations, editorials, statements or theoretical papers.

\subsection{Retrieval of the Studies}

The study retrieval was conducted in four phases. In the first phase, as a result of database searches, a total of 5,413 studies were identified: CINAHL $n=1,945$, Web of Science $n=1,695$, 
Scopus $n=975$, PubMed $n=760$ and Cochrane $n=38$. In the second phase, titles were screened and duplicates removed; hence, a total of 263 studies met the inclusion criteria and were selected to be screened by abstract. Additionally, a manual search provided two studies. In the third phase, studies were screened by abstract and the screening was conducted independently by two authors (A. S-J. \& E. H.), resulting in a total of 85 studies selected for full-text assessment. Altogether, 181 studies were excluded by abstract because they did not meet the inclusion criteria or suit the topic of the review. At this point of the appraisal, a limitation on language was also imposed so that articles written in languages other than English or Swedish were excluded $(n=11)$. In the fourth phase of the retrieval, full-text articles were assessed by two authors (A. S-J. \& E. H.). At this stage, 62 studies were excluded because they did not concern knowledge or skills, did not include an instrument for knowledge or skill assessment, knowledge and skills were not assessed in detail, the study was conducted in a primary or tertiary care setting, study participants were mainly taking care of non-palliative patients, nurses and other healthcare professionals could not be identified in the study results or the study only considered educational programmes. Eventually, 23 studies remained and were included in the quality appraisal (Fig. 1).

\subsection{Quality Appraisal}

The quality assessment in this study was accomplished using the Joanna Briggs Institute's (JBI) seven-item Checklist for Analytical Cross-Sectional Studies quality appraisal tool (JBI, 2017). Studies were scored using the quality appraisal tool, with answer option 'yes' assigned one point and options 'no' and 'unclear' assigned zero points.

The quality appraisal was conducted by four authors: (A. S-J. \& T. L.), (A. S-J. \& E. H.) and (A. S-J. \& M. H.). Following an independently conducted assessment, an absolute consensus was achieved through discussion. The final assessments were confirmed by two of the authors (A. S-J. \& E. H.). 
The quality of the studies was generally good, but there were some variations between studies. The overall quality scores ranged from $3 / 5$ to $5 / 5$ and $5 / 7$ to $6 / 7$, but the variation in the number of applicable criteria between different studies was taken into consideration. The scale for the appraisal of the studies was either $0-5$ or $0-7$, depending on how many of the criteria were included in each of the studies (Table 1).

\subsection{Data Analysis}

The initial data analysis phase involved compiling all the included studies into a table to obtain an overall view of the studies. General information about the studies was tabulated and this included the authors, year and country of publication, the purpose of the study, study design, number and description of participants, data collection method, analysis methods and outcomes of the study (Table 1).

Thereafter, a qualitative content analysis of the instruments was conducted by three of the authors (A. S-J., E. H. \& M. H) based on the research questions and the aim of this review as stated previously (Aveyard, 2007; Whittemore \& Knafl, 2005). The sentences or definitions describing nurses' knowledge and skills were identified and collated as original expressions, exactly as they were written in the instruments. After the original expressions had been collected and collated, they were reduced to their essential content (Elo \& Kyngäs, 2008). Thereafter, the simplified, reduced expressions were analysed so that similar content could be identified and categorised. This categorisation was refined and repeated several times in order to maintain the consistency of the reduced expressions' content and to find the common factors between the expressions; thus, categorised expressions with similar content were classified as subcategories. Subcategories were then combined into categories that unified the content and, finally, these were synthesised into main categories (Table 2). 
The psychometric properties of the instruments used were evaluated by examining the features of the ten instruments reported in the studies; for example, validity, feasibility, repeatability and sensitivity to change (Table 3 ).

\section{Results}

\subsection{Description of the Studies}

A total of 23 studies were included in this review (Table 1). Most of the studies were published between 2012 and 2018 and only two of the studies were published earlier. All of the studies were conducted in specialised hospital settings in Japan $(n=5)$, the USA $(n=4)$, Korea $(n=3)$, Spain $(n=2)$, Iran $(n=2)$, Canada $(n=2)$, and one study each in Israel, Taiwan, Vietnam, Saudi-Arabia and Norway. Except for one study, all the study designs were cross-sectional and most of the studies took a descriptive approach. All of the studies were conducted using a quantitative method; however, a few studies also contained a minor qualitative component. The sample size varied from 90 to 7,922 and most of the participants were nurses, although two of the studies included other healthcare professionals, with the participation of the nurses reported separately (Lazenby et al., 2012; Montagnini et al., 2018).

Overall, ten instruments were identified from the included studies (Table 3). Five of the instruments had a component for knowledge assessment, and five of the instruments were selfevaluation tests.

\subsection{Nurses' Palliative Care Knowledge and Skills}

Nurses' palliative care knowledge and skills were defined according to three main categories: 1) care for the patient, 2) care for the patient's family, and 3) professional requirements (Table 2). Nurses' knowledge and skills, as defined in the instruments, described patients' holistic care, taking into account the different areas of life in the care of dying patients. The basis of palliative care knowledge and skills is an understanding of the core palliative care philosophy that underpins palliative care. In the instruments, care for the family includes similar elements to those 
involved in care for the patient. Nevertheless, care for the family mainly provides mental support for the family and helps the family to cope with the patient's illness. The personal knowledge and skills required of nurses are necessary when dealing with incurably ill patients, death, and dying.

\subsubsection{Palliative care knowledge and skills regarding care for the patient.}

In the instruments, nurses' palliative care knowledge and skills regarding care for the patient were divided into eight categories: 1) the general basis of palliative care, 2) the patient's involvement in his or her own care 3) psychosocial support, 4) spirituality, 5) the cultural aspects of care, 6) pharmacological treatment, 7) physical symptom management and 8) end-of-life care (Table 2).

The general basis of palliative care included two subcategories: knowledge and skills concerning the principles of palliative care and identifying patients' suitability for palliative care. The principles consisted of understanding the philosophy and guidelines of palliative care and recognising the active nature of palliative care, its compatibility with aggressive treatment and its relationship to other treatments. Identifying the suitability of palliative care for a patient and being able to determine when a patient needs palliative care were also important characteristics of the general basis of palliative care (Kim et al., 2011; Choi et al., 2012; Ly et al., 2014; Iranmanesh et al., 2014; Abudari et al., 2014; Shimizu et al., 2016; Chover-Sierra et al., 2017a; Chover-Sierra et al., 2017b; Schnell-Hoehn et al., 2017;

The patient's involvement in his or her own care included two subcategories: supporting the patient's decision-making and supporting the patient in managing his or her daily life. Supporting the patient's decision-making meant communicating with the patient, discussing the patient's care, giving reliable information about the patient's possibility of participating in the decision-making process and making informed decisions regarding the patient's care (Desbiens \& Fillion, 2011; Ly et al., 2014; Price et al., 2017). Supporting the patient in managing their daily life involved an assessment of the needs of the patient as well as helping the patient to maintain his or her 
independence in the activities of daily living (Desbiens \& Fillion, 2011; Ly et al., 2014; Slatten et al., 2014).

Psychosocial support was divided into two sub-categories: identifying patients' psychosocial needs and supporting the patient in coping with a life-limiting illness. The nurse's competence in the identification of the psychosocial needs of the patient included an ability to assess the emotional distress a patient experiences and, secondly, to recognise and understand the patient's grief and sorrow (Kim et al., 2011; Autor et al., 2013; Kim \& Hwang, 2014; Iranmanesh et al., 2014; Price et al., 2017; Schnell-Hoehn et al., 2017). Supporting the patient in coping with a life-limiting illness meant that the nurse had to have the necessary skills to assist the patient in meeting their social needs, promote communication between family members (Desbiens \& Fillion, 2011; Ly et al., 2014) and also provide care such that the patient and his or her family are able to identify resources to cope with the distress and bereavement the illness causes (Desbiens \& Fillion, 2011; Ly et al., 2014; Price et al., 2017; Montagnini et al., 2018).

Spirituality included two subcategories: assessing and recognising patients' spiritual needs and dealing with the spiritual perspectives of the patient. Spirituality included nurses' skills in assessing and recognising the patient's spiritual needs and distress during the dying process, and the nurses' capability in dealing with spiritual and religious perspectives as an element of care (Desbiens \& Fillion, 2011; Ly et al., 2014; Price et al., 2017; Montagnini et al., 2018; Feder et al., 2018).

The cultural aspects of care included two subcategories: identifying cultural needs and considering the cultural aspects of the patient's care. Cultural aspects included nurses' knowledge of cultural factors that affect the patient's care and their ability to support the patient in maintaining cultural traditions at the time of death (Desbiens \& Fillion, 2011; Lazenby et al., 2012; Ly et al., 2014; Price et al., 2017; Feder et al., 2018; Montagnini et al., 2018). 
Pharmacological treatment included two subcategories: knowledge about the efficacy of the medication and knowledge about the side-effects of drugs that can appear during treatment. Knowledge about the efficacy of the drugs was linked to choosing the right medication according to the patient's symptoms, knowing the interactions between drugs, and understanding the different possible routes for administering medication. Nurses needed knowledge of the side-effects that drugs can cause, especially in situations where incorrect perceptions about adverse effects could hinder the selection of the most effective medication for the palliative care patient (Nakazawa et al., 2009; Choi et al., 2012; Sato et al., 2014; Iranmanesh et al., 2014; Abudari et al., 2014; Shimizu et al., 2016; Chover-Sierra et al., 2017a; Chover-Sierra et al., 2017b; Schnell-Hoehn et al., 2017; Nakazawa et al., 2018).

Management of the physical symptoms consisted of four different subcategories: treatment of respiratory symptoms, treatment of gastro-intestinal symptoms, pain evaluation and pain management. The knowledge and skills concerning the treatment of respiratory symptoms were mainly management of dyspnoea and the ability to treat agonal respiration (Nakazawa et al. 2009; Desbiens \& Fillion 2011; Sato et al. 2014, Ly et al. 2014; Shimizu et al. 2016; Price et al. 2017; Nakazawa et al. 2018). Gastro-intestinal symptom management included care for dryness of the mouth and the treatment of nausea, vomiting and constipation (Desbiens \& Fillion 2011; Slatten et al. 2014; Price et al. 2017). The evaluation of patient's pain consisted of understanding the holistic nature of the pain and its connection to the life-limiting illness and, furthermore, identifying the goals of pain management (Nakazawa et al. 2009; Desbiens \& Fillion 2011; Choi et al. 2012; Sato et al. 2014; Chover-Sierra et al. 2017a; Chover-Sierra et al. 2017b; Schnell-Hoehn et al. 2017; Nakazawa et al. 2018). Pain management required a knowledge of pharmacological treatments, as well as non-pharmacological and complementary interventions to alleviate pain (Desbiens \& Fillion 2011; Choi et al. 2012; Slatten et al. 2014; Price et al. 2017; Chover-Sierra et al. 2017a; ChoverSierra et al. 2017b; Schnell-Hoehn et al. 2017; Montagnini et al. 2018). 
End-of-life care had three subcategories: identifying the symptoms and signs of approaching death in the patient, the physical needs of the patient at the end of life and emotional support. Nurses need to be able to identify the physical needs of the patient in the last stages of life and, in particular, recognise those symptoms that greatly affect the patient's consciousness and discomfort during the dying phase of care. Emotionally, nurses need to be able to discuss impending death and be genuinely present for the patient at the time of death (Nakazawa et al., 2009; Choi et al., 2012; Sato et al., 2014; Shimizu et al., 2016; Chover-Sierra et al., 2017a; Chover-Sierra et al., 2017b; Schnell-Hoehn et al., 2017; Nakazawa et al., 2018).

\subsubsection{Knowledge and skills regarding care for the patient's family.}

When considering care for the family, as defined in the instruments, four different categories of knowledge and skills were identified: 1) involving the family in the care of the patient, 2) psychosocial support, 3) spirituality and 4) the cultural aspects of care (Table 2).

Involving the family in the care of the patient included two subcategories: the family's involvement in care planning and the family's involvement in the care itself. Nurses need to involve the family in care planning by discussing care and treatment, promoting communication (Desbiens \& Fillion, 2011; Price et al., 2017; Montagnini et al., 2018) and helping to alleviate the family’s burden by supporting them in providing care for their loved one (Desbiens \& Fillion, 2011; Ly et al., 2014; Feder et al., 2018).

Psychosocial support consisted of three subcategories: identifying the family's psychosocial needs, supporting them in coping with the patient's illness, and providing support around dying and bereavement. Identification of psychosocial needs is important when assessing the family`s resources and the effects of the patient's illness on family dynamics (Desbiens \& Fillion, 2011; Price et al., 2017; Montagnini et al. 2018). Families also need assistance in finding resources for bereavement and coping with death (Desbiens \& Fillion, 2011; Kim et al., 2011; Choi et al., 2012; Iranmanesh et al., 2012; Autor et al., 2013; Abudari et al., 2014; Kim \& Hwang, 2014; Razban et 
al., 2015; Chover-Sierra et al., 2017a; Chover-Sierra et al., 2017b; Montagnini et al., 2018; Feder et al., 2018).

Spirituality contained two subcategories: identifying the spiritual needs of the family and dealing with spirituality. From a spiritual perspective, nurses must assess what spiritual requirements family member have and recognise their spiritual distress (Desbiens \& Fillion, 2011; Ly et al., 2014; Price et al., 2017; Montagnini et al. 2018). Moreover, nurses should feel comfortable when dealing with families' religious perspectives (Desbiens \& Fillion, 2011; Lazenby et al., 2012; Ly et al. 2014; Feder et al. 2018).

The cultural aspects of care included two subcategories: identifying cultural needs and considering cultural factors in the care for the patient's family. It is important that nurses know how to assist the family in maintaining their cultural traditions when the patient is dying (Desbiens \& Fillion, 2011; Lazenby et al., 2012; Ly et al., 2014; Price et al., 2017; Feder et al., 2018; Montagnini et al., 2018).

\subsubsection{The professional knowledge and skill requirements of nurses.}

In the instruments, nurses' personal requirements in palliative care were distributed across four categories: 1) personal resources, 2) collaboration skills, 3) ethics and 4) coping with death (Table 2).

Personal resources included two subcategories: identifying personal needs and resources when caring for dying people, and workplace support for staff. Nurses must have skills in managing stress and adapting to the loss of patients (Desbiens \& Fillion, 2011; Kim et al., 2011; Choi et al., 2012; Iranmanesh et al., 2012; Lazenby et al., 2012; Autor et al., 2013; Abudari et al., 2014; Ly et al., 2014; Kim \& Hwang, 2014; Razban et al., 2015; Chover-Sierra et al., 2017a; Chover-Sierra et al., 2017b; Schnell-Hoehn et al., 2017). Workplace support included the skills to identify the support provided by the workplace and the ability to give support to colleagues (Lazenby et al., 2012; Feder et al. 2018). 
Collaboration skills were divided into two subcategories: interpersonal skills and multidisciplinary skills. Nurses, for example, need to have skills for communicating with the patient and his or her family members, and also to be able to communicate and collaborate with other professionals concerning the patient's care (Desbiens \& Fillion, 2011; Slatten et al., 2014; Feder et al., 2018).

Ethics comprised two subcategories: identifying ethical issues and dealing with those ethical issues. Nurses have to recognise that consideration of ethical issues is essential in palliative care and they need to know how to provide advocacy and guidance for the patient when ethical issues relate to the care they provide (Desbiens \& Fillion, 2011; Slatten et al., 2014; Arahata et al., 2018).

Coping with death consisted of two subcategories: preparedness for the patient's death and adaptation to dying. Preparedness for death requires nurses to know how to deal with death and dying and prepare for the moment of death (Slatten et al., 2014; Price et al., 2017; Arahata et al., 2018; Montagnini et al., 2018). Adaptation to dying means that nurses can cope with the grief and loss they experience when the patient dies (Desbiens \& Fillion, 2011).

\subsection{Instruments used for knowledge and skill assessment.}

Nurse's knowledge and skills were evaluated through knowledge tests and self-assessed skill-evaluation tools. Overall, ten instruments were identified from the included studies (Table 3). Five of the instruments had a component for knowledge assessment. The Palliative Care Quiz for Nursing (PCQN - instrument) (20 items) to assess nurses' palliative care knowledge, End-of-Life Nursing Education Consortium-Japan Core Quiz (ELNEC-JC-Q - instrument) included 90 items in 9 domains assessing nurses' knowledge in end-of-life care. This instrument had also a component for attitude evaluation, which was not analysed in this review. Questionnaire on the Knowledge, Attitudes, and Behavioural Intentions of Medical personnel in Providing Artificial Nutrition and Hydration was a seven-part questionnaire including a 17 item component assessing medical personnel's knowledge in providing artificial nutrition to palliative care patients. The instrument 
had components for attitudes and behavioural intentions in providing artificial nutrition too, although those components did not meet the aim of this review. The Palliative Care Knowledge Test (PCKT - instrument) was a knowledge test to assess nurses' knowledge in palliative care. The instrument consisted of 40 items. Shimizu et al. 2016 self-developed scales had 31 items to assess nurses' knowledge about palliative care. The instrument had also other components to evaluate palliative care difficulties and self-reported practices, but those were not analysed in this review.

The most commonly used knowledge test is the Palliative Care Quiz for Nursing (PCQN), which was used in ten of the studies. Knowledge in the knowledge instruments was assessed using items with 'true' or 'false' answer options (Ke et al., 2008; Kim et al., 2011; Choi et al., 2012; Autor et al., 2013; Abudari et al., 2014; Iranmanesh et al., 2014; Kim \& Hwang, 2014; Shimizu et al., 2016; Chover-Sierra et al., 2017a; Chover-Sierra et al., 2017b; Schnell-Hoehn et al., 2017) or 'right' or 'wrong' answers (Nakazawa et al., 2009; Sato et al., 2014; Arahata et al., 2018; Nakazawa et al., 2018). The knowledge items mainly evaluated nurses' knowledge of the philosophy, ethics, and principles of palliative care; pain and symptom management; pharmacological care; psychological, social and cultural care; and care at the end of life (Table 3).

Nurse's palliative care skills were evaluated through self-assessment in five of the instruments (Table 3). The Palliative Care Nursing Self-competence Scale (PCNSC - instrument) was developed to evaluate nurses self-perceived skills in palliative care competencies with 10 items. The End-of-Life Professional Caregiver Survey (EPCS - instrument) evaluated end-of-life professional caregiver's core competencies in palliative care by 28 items. The End-of-Life Questionnaire (EOL - instrument), just like The Scale of End-Of-Life Care in ICU (EOL-ICU), were both evaluating healthcare professionals' self-perceived confidence in providing end-of-life care by 28 items. The EOL - instrument were developed to be used in hospitalised settings and EOL-ICU in intensive care units. Nurses Core Competencies in Palliative Care (NCPC - 
instrument) evaluated nurses' agreement of the skills in palliative care core competencies by 26 items.

Skills were mostly evaluated by asking how strongly participants agreed with certain statements and were assessed using Likert-scales (Slatten et al., 2014; Price et al., 2017; Feder et al., 2018; Montagnini et al., 2018) or strength of self-assessed competence (Desbiens \& Fillion, 2011). Instruments for skill evaluation included 10 to 28 items in different areas. Nurses' self-evaluated skills were assessed in relation to pain and other symptom management, psychological care, social care, spiritual care, cultural care, ethical and legal issues, inter-professional collaboration, communication, personal and professional issues connected to nursing care, end-of-life care, decision-making, continuity of care and organisational support for staff (Table 3).

The instruments assessing knowledge and skills shared content in most of the item subscales. These included pain and symptom management; psychological, social, cultural and spiritual care; and ethics. Knowledge tests included items concerning the philosophy and principles of palliative care, which were not assessed by the skill-measuring instruments. The skill evaluation instruments differed in that they included items about collaboration and communication, personal and professional issues, decision-making, continuity of care and organisational support, which the knowledge tests did not include.

\subsection{Validity and reliability of measurement instruments.}

The assessment of validity and reliability focused mainly on content validity, construct validity, structural validity and internal consistency (Table 3). Content validity was reported as the content validity index for three instruments (PCQN, PCNSC, Questionnaire on the Knowledge, Attitudes, and Behavioral Intentions of Medical Personnel in Providing Artificial Nutrition), performing between 0.85 and 0.95 . Construct validity was reported as 'good' or 'acceptable' for two of the instruments (NCPC, Shimizu et al., 2016). Item response theory (IRT), which was used to analyse the structural validity of the instruments, were reported for three of the instruments 
(PCQN; PCKT; Shimizu et al., 2016). The validity assessment of the instruments was mainly based on their internal consistency and construct validity, which were not commonly reported in most of the studies; however, validity of the instruments was evaluated and accepted by experts in some cases (Ke et al., 2008; Kim et al., 2011; Ly et al., 2014; Iranmanesh et al., 2014; Razban et al., 2015; Feder et al., 2018). Validity was also reported to be acceptable for some instruments (NCPC; PCKT; Shimizu et al., 2016; PCQN; EOL-Q).

The internal consistency was reported as a Kuder-Richardson formula (KR-20) for four of the instruments (PCQN; ELNEC_-JCQ; PCKT; Questionnaire on the Knowledge, Attitudes, and Behavioral Intentions of Medical Personnel in Providing Artificial Nutrition) and this varied from 0.67 to 0.81 . The internal consistency was also reported using Cronbach's alpha for seven of the instruments and it varied from 0.67 to 0.96 when considering the overall results for all of the items, although the Cronbach's alphas varied for individual items (Table 3). Some of the studies, especially those that used PCQN (Choi et al., 2012; Autor et al., 2013; Iranmanesh et al., 2014; Abudari et al., 2014; Chover-Sierra et al., 2017b; Schnell-Hoehn et al., 2017) or studies that used an instrument that had been recently validated (Sato et al., 2014; Nakazawa et al., 2018), reported reliability based on previous studies (Table 3). The intraclass correlation coefficient or Cohen's kappa coefficient was reported for two of the instruments (ELNEC-J-CQ, PCKT), ranging between 0.84 and 0.88 and indicating acceptable relative repeatability, and some of the studies reported the internal reliability of the instrument to be reliable based on several different statistical analyses (Lazenby et al., 2012; Slatten et al., 2014).

\section{Discussion}

It is important to find instruments that are reliable and valid, but also have suitable content for assessing nurses' expertise in palliative care nursing. Several instruments have been used to evaluate nurses' competence in palliative care (Hujer et al., 2009; Bing-Jonsson et al., 2014; Mager \& Lang, 2016; Yaakup et al., 2014) and competence assessment is assumed to significantly improve 
the skills of nurses (Desbiens et al., 2011). In this integrative review, the content of the ten instruments for measuring nurses' palliative care knowledge and skills can be separated into three different categories: 1) care for the patient, 2) care for the patient's family and 3) professional requirements (Table 2). The nurses' knowledge and skills, as defined in the instruments, mainly followed the definition of palliative care nursing (Sherman et al., 2010) and the international guidelines for palliative nursing competence, taking the physical, psychological, social, spiritual, cultural, end-of-life, ethical and legal aspects of care, patients and their families, cooperation and multi-professionalism, interaction skills, identification of personal skills and continuing professional development into account (Gamondi et al. 2013; Ferrell et al., 2018). In the studies, the instruments were reported to be valid and reliable for use in knowledge and skill assessment, although the evaluation was not particularly extensive for all the instruments. There were also differences in the reliability and validity of the same instrument as reported in different studies, especially when the instrument was used in different countries and cultures. This was mainly evident with the PCQN instrument, which has been utilised in several nations. The validity and reliability reported in original study were not convergent in all cases when the instrument was used in a different cultural environment, although the instrument was deemed to be acceptable (Choi et al., 2012; Chover-Sierra et al., 2017a).

Healthcare professionals need to have sufficient ability to provide palliative care (Weissman \& Blust, 2005; Miyashita et al., 2007; Hales et al., 2010; Schulman-Green et al., 2011; Gamondi et al., 2013). In particular, the nurses' expertise in palliative care is a significant factor affecting the quality of the care (Huijer et al., 2009). The instruments analysed in this review assessed nurses' knowledge and skills through knowledge tests and skill-evaluation self-tests. The knowledge tests aimed to evaluate nurses' level of knowledge through 'right' or 'wrong' answers. These types of instruments can be used to evaluate nurses' knowledge in situations where there is a need to have objective information about the level of knowledge. Self-evaluation instruments assessed nurses' 
self-perceived skills in different areas of palliative care using Likert-scales. Skill-measuring instruments are appropriate when nurses' own opinion of their expertise is required.

\subsection{Strengths and Limitations}

The review was conducted following Whittemore and Knafl's (2005) integrative review methodology that includes a plan agreed by the team, review questions, inclusion and exclusion criteria, and approaches to data extraction and analysis to ensure the repeatability of the study. PRISMA guidelines for systematic literature reviews and meta-analyses were also followed to ensure explicit reporting (Moher et al., 2009). At least two members of the team were included at all stages with arbitration, if required provided by a third team member. All members of the team agreed on the final analysis.

In order to cover the research topic accurately, and to obtain reliable results and studies (Conn et al., 2003), the database search was comprehensive. The search strategy was developed using MeSH terms and the expertise of the librarian. The Boolean operators 'AND' and 'OR' were used to create search phrases. Search and review results were recorded using PRISMA. The review of the abstracts and full texts, as well as the evaluation of the quality of the studies, was carried out by two independent reviewers to increase the reliability of the study selection and quality assessment. The content analysis process was undertaken by three reviewers and there was a high level of agreement regarding the findings. The final agreement on the findings resulted from discussion between members of the author team.

There are also some limitations to consider in this review. The quality assessment had limitations due to the JBI criteria not fully corresponding to all the research settings and content of the studies. There was a need to formulate a common view on the use and interpretation of the criteria among the evaluators so that the estimates would be consistent. This may have affected the results of the assessment of the quality. There was also some variation in the quality of the studies and differences existed regarding the grade of study design and methods in some extend, which 
should be considered when evaluating the generalisation of the results of this study. At the abstract analysis stage, studies were restricted to articles written in English or Swedish. It is possible that some information has been excluded from the review due to language limitations; however, the search produced plenty of studies and only a few of the studies were excluded by language.

\section{Conclusions}

There are several knowledge tests and self-evaluation instruments for assessing nurses' palliative care knowledge and skills. In the instruments, the nurses' knowledge and skills in specialised palliative care settings reflect the criteria of holistic care of the patient, assisting the family and ensuring access to adequate professional resources. The content of the instruments followed the international guidelines for the core areas of palliative care competence (Gamondi et al. 2013; Ferrell et al., 2018). The psychometric properties of the instruments were reported to varying degrees, mainly focusing on internal consistency and content validation. The cultural differences and national guidelines that might have influenced the development and content of the instruments must be taken into consideration when selecting appropriate instruments for evaluation. Validation of the existing instruments for use in other cultures offers an opportunity to broaden the use of the instruments internationally.

\section{Relevance to Clinical Practice}

This review generated knowledge about the instruments that can be used when evaluating the palliative care knowledge and skills of nurses working in specialised care settings. The instruments used for palliative care knowledge and skill assessment were designed and described according to their content and psychometric properties.

This review provides an overall description of instruments for assessing palliative care knowledge and skills in specialised care settings. The results can be utilised to improve the quality of palliative care by evaluating the knowledge and skills of nursing staff. In addition, the results can be exploited when considering the need for palliative care education or when identifying 
educational gaps by assessing nurses' existing proficiency and identifying a possible lack of knowledge or skill in palliative care expertise. This review considers the content areas of the instruments, but the reliability must be approached with caution and validation studies in other cultures are therefore recommended.

\section{References}

Abudari, G., Zahreddine, H., Hazeim, H., Al Assi, M., \& Emara, S. (2014). Knowledge of and attitudes towards palliative care among multinational nurses in Saudi Arabia. International Journal of Palliative Nursing 20, 435-441. doi: 10.12968/ijpn.2014.20.9.435

Ahmed, N., Bestall, J. E., Ahmedzai, S. H., Payne, S. A., Clark, D., \& Noble, B. (2004). Systematic review of the problems and issues of accessing specialist palliative care by patients, carers and health and social care professionals. Palliative Medicine 18, 525-542. doi:

$10.1191 / 0269216304 \mathrm{pm} 921$ oa

Arahata, T., Miyashita, M., Takenouchi, S., Tamura, K., \& Kizawa, Y. (2018). Development of an Instrument for Evaluating Nurses' Knowledge and Attitude Toward End-of-Life Care: End-of-Life Nursing Education Consortium--Japan Core Quiz. Journal of Hospice \& Palliative Nursing 20, 5562. doi: 10.1097/NJH.0000000000000393

Autor, S.H., Storey, S.L., \& Ziemba-Davis, M. (2013). Knowledge of palliative care: An evaluation of oncology, intensive care, and heart failure nurses. Journal of Hospice and Palliative Nursing 15, 307-315.

Aveyard, H. (2007). Doing a literature review in health \& social care. A practical guide. Berkshire: McGraw Hill Companies.

Bing-Jonsson, P. C., Bjork, I. T., Hofoss, D., Kirkevold M., \& Foss C. (2014). Competetnce in advanced older people nursing: development of 'Nursing older people - Competetnce evaluation tool'. International Journal of Older People Nursing 10, 59-72. doi: 10.1111/opn.12057

Choi, M., Lee, J.H., Kim, S., Kim, D., \& Kim, H. (2012). Nurses' knowledge about end-of-life care: Where are we? Journal of Continuing Education in Nursing 43, 384. doi: 10.3928/0022012420120615-35

Chover-Sierra, E., Martinez-Sabater, A., \& Lapena-Monux, Y. (2017a). Knowledge in palliative care of nursing professionals at a Spanish hospital. Revista Latino-Americana De Enfermagem 25. doi:10.1590/1518-8345.1610.2847

Chover-Sierra, E., Martinez-Sabater, A., \& Lapena-Monux, Y.R. (2017b). An instrument to measure nurses' knowledge in palliative care: Validation of the Spanish version of Palliative Care Quiz for Nurses. PloS One 12, e0177000. doi: 10.1371/journal.pone.0177000

Connolly, M., Charnlay, K., \& Regan, J. (2012). A Review of Palliative Care Competence Frameworks. Retrieved from https://aiihpc.org/wp-content/uploads/2014/12/Palliative-CareCompetence-Framework-Report-Project-Group.pdf 
Connolly, M., Ryan, K., \& Charnlay, K. (2016). Developing a palliative care competence framework for health and social care professionals: the experience in the Republic of Ireland. Supportive and Palliative Care 6(2), 237-242. doi: 10.1136/bmjspcare-2015-000872

Desbiens, J., \& Fillion, L. (2011). Development of the Palliative Care Nursing Self-competence Scale. Journal of Hospice \& Palliative Nursing 13, 230-241. doi: 10.1097/NJH.0b013e318213d300

Desbiens, J.-F., Gagnon, J., \& Fillion L. (2011). Development of a shared theory in palliative care to enhance nursing competence. Journal of Advanced Nursing 68(9), 2113-2124. doi:

$10.1111 / \mathrm{j} .1365-2648.2011 .05917 . \mathrm{x}$

Elo, S., \& Kyngas, H. (2008). The qualitative content analysis. Journal of Advanced Nursing 62(1),107-115. doi: 10.1111/j.1365-2648.2007.04569.x

Espinosa, L., Young, A., \& Walsh, T. (2008). Barriers to Intensive Care Unit Nurses Providing Terminal Care: An Integrated Literature Review. Critical Care Nursing Quarterly 31(1), 83-93. doi: 10.1097/01.CNQ.0000306402.55518.da

Eurostat (2018). Population structure and ageing. Retrieved from https://ec.europa.eu/eurostat/statistics-explained/index.php?title=Population_structure_and_ageing

Feder, S. L., Collett, D., Haron, Y., Conley, S., Schulman-Green, D., Meron, T., \& Cherny, N. (2018). How skilled do Israeli nurses perceive themselves to be in providing palliative care? Results of a national survey. International Journal of Palliative Nursing 24, 56-63. doi:

10.12968/ijpn.2018.24.2.56

Ferrell, B. R., Twaddle, M. L., Melnick, A., \& Meier, D. E. (2018). National Consensus Project Clinical Practice Guidelines for Quality Palliative Care Guidelines, 4th Edition. Journal of palliative medicine 21(12), 1684 -1689. doi: 10.1089/jpm.2018.0431

Gamondi, C., Larkin, P., \& Payne S. (2013). Core competencies in palliative care: An EAPC White Paper on palliative care education -part 1. European Journal of Palliative Care 20(2), 86-145.

Hales, S., Zimmermann, C., \& Rodin, G. (2010). Review: The quality of dying and death: a systematic review of measures. Palliative Medicine 24(2), 127-144. doi:

$10.1177 / 0269216309351783$

Haltia, O., Farkkila, N., Roine, R. P., Sintonen, H., Taari, K., Hanninen, J., Lehto, J. T., \& Saarto, T. (2018). The indirect costs of palliative care in end-stage cancer: A real-life longitudinal registerand questionnaire-based study. Palliative Medicine 32(2), 493-499. doi: 0.1177/0269216317729789

Harris, M., Gaudet, J., \& O'Reardon, C. (2014). Nursing care for patients at end of life in the adult intensive care unit. Journal of Nursing Education and Practice 4(6), 84-89. doi: http://dx.doi.org/10.5430/jnep.v4n6p84

Huijer, H.A., Abboud, S., \& Dimassi, H. (2009). Palliative care in Lebanon: knowledge, attitudes and practices of nurses. International Journal of Palliative Nursing 15, 346-353. doi:

10.12968/ijpn.2009.15.7.43425 
Iranmanesh, S., Razban, F., Tirgari, B., \& Zahra, G. (2014). Nurses' knowledge about palliative care in Southeast Iran. Palliative \& Supportive Care 12, 203-210. doi:

$10.1017 /$ S 1478951512001058

JBI (2017). The Joanna Briggs Institute Critical Appraisal tools for use in JBI Systematic Reviews Checklist for Analytical Cross Sectional Studies. Retrieved from

http://joannabriggs.org/research/critical-appraisal-tools.html

Ke, L., Chiu ,T., Lo, S., \& Hu, W. (2008). Knowledge, attitudes, and behavioral intentions of nurses toward providing artificial nutrition and hydration for terminal cancer patients in Taiwan. Cancer Nursing 31, 67-76. doi: 10.1097/01.NCC.0000305672.98587.63

Kim, H.S., Kim, B.H., Yu, S.J., Kim, S., Park, S.H., Choi, S., \& Jung, Y. (2011). The effect of an End-Of-Life Nursing Education Consortium course on nurses' knowledge of hospice and palliative care in korea. Journal of Hospice \& Palliative Nursing 13, 222-229. doi:

10.1097/NJH.0b013e318210fdec

Kim, S., \& Hwang, W.J. (2014). Palliative care for those with heart failure: Nurses' knowledge, attitude, and preparedness to practice. European Journal of Cardiovascular Nursing 13, 124-133. doi: $10.1177 / 1474515113519521$

Lazenby, M., Ercolano, E., Schulman-Green, D., \& McCorkle, R. (2012). Validity of the end-of-life professional caregiver survey to assess for multidisciplinary educational needs. Journal of Palliative Medecine 15(4), 427-431. doi: 10.1089/jpm.2011.0246

Ly, T.N., Yates, P., \& Osborne, Y. (2014). Palliative care knowledge, attitudes and perceived selfcompetence of nurses working in Vietnam. International Journal of Palliative Nursing 20, 448-456. doi: 10.12968/ijpn.2014.20.9.448

Mager, D. R., \& Lange, J. W. (2016). The ELDER Project. Evaluating end-of-life knowledge among health care providers. Journal of Hospice and Palliative Nursing 18(1), 22-28. doi: 10.1097/NJH.0000000000000199

Miyashita, M., Sanjo, M., Morita, T., Hirai, K., \& Uchitomi Y. (2007). Good death in cancer care: a nationwide quantitative study. Annals of Oncology 18(6), 1090-1097. doi: 10.1093/annonc/mdm068

Moher, D., Liberati, A., Tetzlaff, J., Altman, D.G., \& The PRISMA Group (2009). Preferred Reporting Items for Systematic Reviews and Meta-Analyses: The PRISMA Statement. PLoS Med 6(7): e1000097. doi:10.1371/journal.pmed1000097

Montagnini, M., Smith, H.M., Price, D.M., Ghosh, B., \& Strodtman, L. (2018). Self-Perceived Endof-Life Care Competencies of Health-Care Providers at a Large Academic Medical Center. American Journal of Hospice \& Palliative Medicine 35, 1409-1416. doi: $10.1177 / 1049909118779917$

Nakazawa, Y., Miyashita, M., Morita, T., Umeda, M., Oyagi, Y., \& Ogasawara, T. (2009). The palliative care knowledge test: reliability and validity of an instrument to measure palliative care knowledge among health professionals. Palliative Medicine 23, 754-766. doi: $10.1177 / 0269216309106871$ 
Nakazawa, Y., Kato, M., Miyashita, M., Morita, T. \& Kizawa, Y. (2018). Changes in Nurses' Knowledge, Difficulties, and Self-reported Practices Toward Palliative Care for Cancer Patients in Japan: An Analysis of Two Nationwide Representative Surveys in 2008 and 2015. Journal of Pain \& Symptom Management 55, 402-412. doi: 10.1016/j.jpainsymman.2017.08.034

Price, D.M., Strodtman, L., Montagnini, M., Smith, H.M., Miller, J., Zybert, J., Oldfield, J., Policht, T. \& Ghosh, B. (2017). Palliative and End-of-Life Care Education Needs of Nurses Across Inpatient Care Settings. Journal of Continuing Education in Nursing 48, 329-336. doi: 10.3928/00220124-20170616-10

Razban, F., Tirgari, B., \& Iranmanesh, S. (2015). Nurses' knowledge about and attitude towards palliative care in Southeast Iran. Asian J. Nursing Edu. and Research 5(3), 399-404. doi: 10.5958/2349-2996.2015.00080.4

Sato, K., Inoue, Y., Umeda, M., Ishigamori, I., Igarashi, A., Togashi, S., Harada, K., Miyashita, M., Sakuma, Y., Oki, J., Yoshihara, R., \& Eguchi, K. (2014). A Japanese Region-wide Survey of the Knowledge, Difficulties and Self-reported Palliative Care Practices Among Nurses. Japanese Journal of Clinical Oncology 44, 718-728. doi: 10.1093/jjco/hyu075

Schnell-Hoehn, K., Estrella-Holder, E., \& Avery, L. (2017). Cardiac Nurses' Knowledge of Palliative Care. Canadian Journal of Cardiovascular Nursing 27, 9-15.

Shimizu, M., Nishimura, M., Ishii, Y., Kuramochi, M., Kakuta, N., \& Miyashita, M. (2016). Development and validation of scales for attitudes, self-reported practices, difficulties and knowledge among home care nurses providing palliative care. European Journal of Oncology Nursing 22, 8-22. doi: 10.1016/j.ejon.2016.02.009

Schulman-Green, D., Ercolano, E., Jeon, S., \& Dixon, J. (2012). Validation of the Knowledge of Care Options Instrument To Measure Knowledge of Curative, Palliative, and Hospice Care. Journal of Palliative Medicine 10(15), 1091-1099. doi: https://doi.org/10.1089/jpm.2011.0514

Schulman-Green, D., Ercolano, E., LaCoursiere, S., Ma, T., Lazenby, M., \& McCork1, R. (2011). Developing and Testing a Web-Based Survey to Assess Educational Needs of Palliative and Endof-Life Health Care Professionals in Connecticut. American Journal of Hospice \& Palliative Medicine 28(4), 219-229. doi: 10.1177/1049909110385219

Sherman, D.W., Matzo, M., \& Metheny, T. (2010). The Interprofessional Practice of Palliative Care Nursing. In A Matzo, M \& Sherman, D.W. (Eds.), Palliative Care Nursing: Quality Care to the End of Life (pp. 3-20). New York: Springer Publishing Company.

Slatten, K., Fagerström, L., \& Hatlevik, O. E. (2010). Clinical competence in palliative nursing in Norway: The importance of good care routines. International journal of palliative nursing 16(2), 80-86. doi: 10.12968/ijpn.2010.16.2.46753

Slatten, K., Hatlevik O., \& Fagerstrom, L. (2014). Validation of a new instrument for selfassessment of nurses' core competencies in palliative care. Nursing Research and Practice 2014, 615-498. doi: 10.1155/2014/615498

Weissman, D. E., \& Blust, L. (2005). Education in Palliative Care. Clinics in Geriatric Medicine 21(1), 165-175. doi https://doi.org/10.1016/j.cger.2004.08.004 
White, K., \& Coyne, P. (2011). Nurses' perceptions of educational gaps in delivering end-of-life care. Oncology Nursing Forum 38(6), 711-717. doi: 10.1188/11.ONF.711-717

Whittemore, R., \& Knafl, K. (2015). The integrative review: updated methodology. Journal of Advanced Nursing 52(5), 546-555. doi: 10.1111/j.1365-2648.2005.03621.x

WHO (2019) WHO Definition of Palliative Care. Retrieved from https://www.who.int/cancer/palliative/definition/en/

WHO (2018) Ageing and health. Retrieved from https://www.who.int/news-room/factsheets/detail/ageing-and-health

WPCA \& WHO (2014) Global Atlas of Palliative Care at the End of Life. Retrieved from http://www.who.int/ncds/management/palliative-care/palliative-care-at-las/en

Yaakup, H., Eng T. C., \& Shah S. A. (2014). Does clinical experience help oncology nursing staff to deal with patient pain better than nurses from other disciplines? Knowledge and attitudes survey amongst nurses in tertiary care in Malaysia. Asian Pacific Journal of Cancer Prevention 15, 48854891. doi: 10.7314/apjcp.2014.15.12.4885 


\section{Tables}

TABLE 1. Studies included in the review

\begin{tabular}{|c|c|c|c|c|c|c|c|}
\hline Study & Purpose & Design & Participants & Data collection & Analysis & Outcome & Quality (JBI) \\
\hline $\begin{array}{l}\text { Abudari et al. } \\
\text { 2014, Saudi } \\
\text { Arabia }\end{array}$ & $\begin{array}{l}\text { To assess knowledge of and } \\
\text { attitudes towards palliative care }\end{array}$ & $\begin{array}{l}\text { A descriptive cross- } \\
\text { sectional }\end{array}$ & $\begin{array}{l}\mathrm{N}=731 \text { nurses from } 30 \\
\text { different nationalities } \\
\text { (working at the } \\
\text { hospital), } \\
\mathrm{n}=395\end{array}$ & $\mathrm{PCQN}^{\dagger}$ & $\begin{array}{l}\text { Descriptive statistics, } \\
\text { independent t-test (to } \\
\text { compare knowledge and } \\
\text { attitudes), ANOVA (post hoc } \\
\text { pair-wise comparisons), } \\
\text { Pearson's correlations, } \\
\text { multiple regression analysis }\end{array}$ & $\begin{array}{l}\text { Knowledge of palliative } \\
\text { care was low (mean } \\
9,06 / 20 \text { ) and attitudes } \\
\text { towards palliative care } \\
\text { moderate }(111,66 / 150) \text {. } \\
\text { Palliative care training, } \\
\text { nursing experience and } \\
\text { the level of palliative care } \\
\text { integration in health care } \\
\text { in the nurses home } \\
\text { country significantly } \\
\text { affected the scores. }\end{array}$ & $4 / 5$ \\
\hline $\begin{array}{l}\text { Autor et al. } \\
2013 \text {, USA }\end{array}$ & $\begin{array}{l}\text { To assess knowledge of palliative } \\
\text { care }\end{array}$ & Cross-sectional & $\begin{array}{l}\mathrm{N}=251 \text { oncology, } \\
\text { intensive care and heart } \\
\text { failure nurses, } \\
\mathrm{n}=143\end{array}$ & $\mathrm{PCQN}^{\dagger}$ & $\begin{array}{l}\text { ANOVA (to compare the } \\
\text { mean of correct responses by } \\
\text { unit), student t-test (to assess } \\
\text { differences of correct } \\
\text { answers based on } \\
\text { experience) } \\
\text { Pearson correlation } \\
\text { coefficient }\end{array}$ & $\begin{array}{l}\text { Nurses were moderately } \\
\text { but not fully } \\
\text { knowledgeable about } \\
\text { palliative care (correct } \\
\text { responses } 67,6 \% \text { ). } \\
\text { Number of palliative } \\
\text { patients cared for, } \\
\text { experience or awareness } \\
\text { of institutions palliative } \\
\text { care team were not related } \\
\text { to the correct answers. }\end{array}$ & $4 / 5$ \\
\hline $\begin{array}{l}\text { Arahata et al. } \\
\text { 2018, Japan }\end{array}$ & $\begin{array}{l}\text { To develop a scale of knowledge } \\
\text { and attitudes toward palliative and } \\
\text { EOL care and to confirm the } \\
\text { validity and reliability of the scale. }\end{array}$ & Cross-sectional & $\begin{array}{l}\mathrm{N}=1745 \text { nurses of } 10 \\
\text { hospitals, } \\
\mathrm{n}=762\end{array}$ & ELNEC-J-CQ $\ddagger$ & $\begin{array}{l}\text { IRT, } \kappa \text { coefficient, } \\
\text { exploratory factor analysis } \\
\text { (selection of the items), ICC, } \\
\text { Cronbach's } \alpha \text { (internal } \\
\text { consistency and reliability), } \\
\text { known group validity } \\
\text { (differences between groups) }\end{array}$ & $\begin{array}{l}\text { The ELNEC-J CQ is valid } \\
\text { and reliable to evaluate } \\
\text { knowledge and attitudes } \\
\text { towards palliative care for } \\
\text { nurses. }\end{array}$ & $5 / 5$ \\
\hline $\begin{array}{l}\text { Choi et al. 2012, } \\
\text { Korea }\end{array}$ & $\begin{array}{l}\text { To examine nurses' knowledge of } \\
\text { end-of-life care and its relations to } \\
\text { nurses' characteristics. }\end{array}$ & $\begin{array}{l}\text { Descriptive, } \\
\text { correlational study }\end{array}$ & $\begin{array}{l}\mathrm{N}=400 \text { nurses at two } \\
\text { university hospitals, } \\
\mathrm{n}=368\end{array}$ & $\mathrm{PCQN}^{\dagger}$ & $\begin{array}{l}\text { Descriptive statistics, t-test, } \\
\text { Pearson correlation, } \\
\text { ANOVA }\end{array}$ & $\begin{array}{l}\text { The mean score of the } \\
\text { knowledge was low } \\
(8,95 / 20) \text {. To provide } \\
\text { optimal end-of-life care } \\
\text { there is need for } \\
\text { continuing education. }\end{array}$ & $5 / 5$ \\
\hline $\begin{array}{l}\text { Chover-Sierra et } \\
\text { al. 2017a, Spain }\end{array}$ & $\begin{array}{l}\text { Adaptation of the PCQN - } \\
\text { instrument into the Spanish } \\
\text { language. }\end{array}$ & $\begin{array}{l}\text { Descriptive, cross- } \\
\text { sectional }\end{array}$ & $\mathrm{n}=159$ & $\mathrm{PCQN}^{\dagger}$ & $\begin{array}{l}\text { CVI, kappa-index (validity), } \\
\text { Cronbach's alpha, KR-20 } \\
\text { (reliability), IRT (difficulty) }\end{array}$ & $\begin{array}{l}\text { The instrument is useful } \\
\text { for measuring Spanish } \\
\text { nurses' knowledge in } \\
\text { palliative care. }\end{array}$ & $4 / 5$ \\
\hline
\end{tabular}




\begin{tabular}{|c|c|c|c|c|c|c|c|}
\hline $\begin{array}{l}\text { Chover-Sierra et } \\
\text { al. } 2017 \mathrm{~b} \text {, Spain }\end{array}$ & $\begin{array}{l}\text { To determine the level of } \\
\text { knowledge in palliative care of } \\
\text { nursing staff at a Spanish tertiary } \\
\text { care hospital. }\end{array}$ & $\begin{array}{l}\text { Descriptive, cross- } \\
\text { sectional study }\end{array}$ & $\begin{array}{l}\mathrm{N}=360 \text { nurses working } \\
\text { in inpatient wards, } \\
\text { emergency unit or } \\
\text { critical care ward, } \\
\mathrm{n}=159\end{array}$ & $\mathrm{PCQN}^{\dagger}$ & $\begin{array}{l}\text { Descriptive analysis, } \\
\text { correlation studies, tests of } \\
\text { independence among the } \\
\text { variables, parametric and } \\
\text { non-parametric tests }\end{array}$ & $\begin{array}{l}\text { The knowledge about } \\
\text { palliative care were } \\
\text { sufficient }(10,8 / 20 \text {, } \\
\text { percentage of right } \\
\text { answers } 54 \%) \text {. Education } \\
\text { about palliative care is } \\
\text { needed. }\end{array}$ & $6 / 7$ \\
\hline $\begin{array}{l}\text { Desbiens \& } \\
\text { Fillion 2011, } \\
\text { Canada }\end{array}$ & $\begin{array}{l}\text { To develop a new instrument to } \\
\text { measure perceived PC nursing } \\
\text { self-competence. }\end{array}$ & $\begin{array}{l}\text { Descriptive design } \\
\text { with qualitative and } \\
\text { quantitative } \\
\text { methods }\end{array}$ & $\begin{array}{l}\mathrm{N}=17 \text { individual } \\
\text { interviews and focus } \\
\text { group, } \mathrm{N}=8 \text { cognitive } \\
\text { interviews }\end{array}$ & $\mathrm{PCNSC}^{\S}$ & $\begin{array}{l}\text { Inductive and deductive } \\
\text { content analysis, focus group } \\
\text { interview, expert group } \\
\text { discussion, CVI, Banduras } \\
\text { SCT. }\end{array}$ & $\begin{array}{l}\text { Palliative Care Nursing } \\
\text { Self-competence Scale } \\
\text { was created. }\end{array}$ & $5 / 5$ \\
\hline $\begin{array}{l}\text { Feder et al. } \\
\text { 2018, Israel }\end{array}$ & $\begin{array}{l}\text { To describe oncology and } \\
\text { palliative care nurses' self- } \\
\text { perceived competence in providing } \\
\text { palliative care and to explore } \\
\text { educations, experiences and } \\
\text { workplace factors influence to } \\
\text { skills. }\end{array}$ & Cross-sectional & $\begin{array}{l}\mathrm{N}=122 \text { oncology and } \\
\mathrm{PC} \text { nurses, } \mathrm{n}=105\end{array}$ & EPCS $^{P}$ & $\begin{array}{l}\text { Descriptive statistics (means, } \\
\text { standard deviations, } \\
\text { percentages to determine } \\
\text { nurses' perceived } \\
\text { competences), sub-score } \\
\text { calculation, one way } \\
\text { ANOVA and Tukey's post } \\
\text { hoc correction (comparisons } \\
\text { of EPCS n=sub-scores) }\end{array}$ & $\begin{array}{l}\text { Nurses felt most } \\
\text { competent in speaking } \\
\text { with other health } \\
\text { professionals about the } \\
\text { care of dying and least in } \\
\text { discussing advance } \\
\text { medical directives with } \\
\text { patients and families. } \\
\text { Perceived work place } \\
\text { support was limited. }\end{array}$ & $5 / 5$ \\
\hline $\begin{array}{l}\text { Iranmanesh et } \\
\text { al. 2012, Iran }\end{array}$ & $\begin{array}{l}\text { To examine oncology and } \\
\text { intensive care nurses' knowledge } \\
\text { about palliative care in Southeast } \\
\text { Iran. }\end{array}$ & $\begin{array}{l}\text { Cross-sectional } \\
\text { descriptive }\end{array}$ & $\begin{array}{l}\mathrm{N}=140 \text { ICU and } \\
\text { oncology nurses, } \\
\mathrm{n}=116\end{array}$ & $\mathrm{PCQN}^{\dagger}$ & $\begin{array}{l}\text { Descriptive statistics, } \\
\text { Pearson correlation } \\
\text { coefficient, independent t } \\
\text { test, one way ANOVA. }\end{array}$ & $\begin{array}{l}\text { Nurses knowledge about } \\
\text { palliative care was low } \\
(7,59 / 20) \text { which may be } \\
\text { connected with Iranian } \\
\text { nurses lack of education } \\
\text { and experience and some } \\
\text { cultural limitations. } \\
\end{array}$ & $5 / 5$ \\
\hline $\begin{array}{l}\text { Ke et al. 2008, } \\
\text { Taiwan }\end{array}$ & $\begin{array}{l}\text { To explore the state of knowledge, } \\
\text { attitudes and behavioral intentions } \\
\text { among nurses from general wards } \\
\text { and ICUs toward providing } \\
\text { artificial nutrition and hydration } \\
\text { for terminal cancer patients. }\end{array}$ & Cross-sectional & $\begin{array}{l}\mathrm{n}=197 \text { nurses from } \\
\text { gastroenterology, } \\
\text { general surgery and } \\
\text { ICU }\end{array}$ & $\begin{array}{l}\text { Questionnaire on the } \\
\text { Knowledge, Attitudes, and } \\
\text { Behavioral Intentions of } \\
\text { Medical personnel in } \\
\text { Providing Artificial } \\
\text { Nutrition and Hydration }\end{array}$ & Frequency, mean, SD. & $\begin{array}{l}\text { Nurses' knowledge about } \\
\text { palliative care was high } \\
\text { (accurate-answer rate } \\
96,75 \% \text { ), knowledge } \\
\text { about ANH was lower (a- } \\
\text { ar 53,67\%). }\end{array}$ & $4 / 5$ \\
\hline $\begin{array}{l}\text { Kim \& Hwang } \\
\text { 2014, South } \\
\text { Korea }\end{array}$ & $\begin{array}{l}\text { To describe nurses' knowledge } \\
\text { and attitude regarding palliative } \\
\text { care and to evaluate how } \\
\text { knowledge of and attitude towards } \\
\text { palliative care in nurses influence } \\
\text { their clinical practice in Soul, } \\
\text { South Korea. }\end{array}$ & $\begin{array}{l}\text { Cross-sectional } \\
\text { descriptive }\end{array}$ & $\begin{array}{l}\mathrm{n}=90 \text { nurses from units } \\
\text { with cardiac patients }\end{array}$ & $\mathrm{PCQN}^{\dagger}$ & $\begin{array}{l}\text { Descriptive statistics, t-test, } \\
\text { ANOVA, correlation and } \\
\text { multiple regression analysis. }\end{array}$ & $\begin{array}{l}\text { Nurses level of knowledge } \\
(48,3 \%) \text { correct answers, } \\
\text { attitude, coping and } \\
\text { preparedness relating to } \\
\text { palliative care were low. } \\
\text { Palliative training is } \\
\text { needed. }\end{array}$ & $5 / 5$ \\
\hline $\begin{array}{l}\text { Kim et al. 2011, } \\
\text { Korea }\end{array}$ & $\begin{array}{l}\text { To describe Korean nurses' } \\
\text { knowledge of hospice and } \\
\text { palliative care and to identify the } \\
\text { effect of the ELNEC-program on } \\
\text { improving knowledge. }\end{array}$ & $\begin{array}{l}\text { Pre-test post-test } \\
\text { design survey }\end{array}$ & $\begin{array}{l}\mathrm{N}=141 \text { nurses } \\
\text { participating the } \\
\text { ELNEC core course, } \\
\mathrm{n}=111\end{array}$ & $\mathrm{PCQN}^{\dagger}$ & $\begin{array}{l}\text { Descriptive statistics, } \\
\text { independent sample t-test, } \\
\text { correlations, one way } \\
\text { ANOVA, paired t-test }\end{array}$ & $\begin{array}{l}\text { Korean nurses who } \\
\text { attended the ELNEC } \\
\text { course had moderate to } \\
\text { high level of knowledge } \\
\text { of hospice and palliative } \\
\text { care }(12,5 / 20) .\end{array}$ & $5 / 7$ \\
\hline
\end{tabular}




\begin{tabular}{|c|c|c|c|c|c|c|c|}
\hline $\begin{array}{l}\text { Lazenby et al. } \\
\text { 2012, USA }\end{array}$ & $\begin{array}{l}\text { To assess the validity of EPCS- } \\
\text { instrument. }\end{array}$ & Cross-sectional & $\begin{array}{l}\mathrm{n}=369 \text { nurses, } \\
\text { physicians and social } \\
\text { workers, including } \\
\mathrm{n}=261 \text { nurses }\end{array}$ & EPCS & $\begin{array}{l}\text { Factor analysis (FA), Kaiser- } \\
\text { Myer Olkin test, Bartlett's } \\
\text { test, Eigen values, the scree } \\
\text { plot, and the interpretability } \\
\text { of the various factor solution. } \\
\text { Item loadings on each factor } \\
\text { were estimated by Oblimin. } \\
\text { Pearson product-moment } \\
\text { correlation, ANOVA), } \\
\text { Bonferroni correction. } \\
\text { multivariate linear } \\
\text { regression, Cronbach's } \\
\text { alpha. }\end{array}$ & $\begin{array}{l}\text { The scale has strong } \\
\text { internal reliability. Each } \\
\text { of its three factors is } \\
\text { distinct and internally } \\
\text { reliable. }\end{array}$ & $5 / 5$ \\
\hline $\begin{array}{l}\text { Ly et al. } 2014, \\
\text { Vietnam }\end{array}$ & $\begin{array}{l}\text { To explore palliative care } \\
\text { knowledge, attitudes and } \\
\text { perceived self-competence of } \\
\text { nurses in oncology settings in } \\
\text { Hanoi, Vietnam. } \\
\text { To examine factors that influence } \\
\text { the knowledge. } \\
\text { Explore relationships between } \\
\text { knowledge, attitudes and self- } \\
\text { competence. }\end{array}$ & $\begin{array}{l}\text { Cross-sectional } \\
\text { survey }\end{array}$ & $\mathrm{n}=251$ oncology nurses & $\mathrm{PCNSC}^{\S}$ & $\begin{array}{l}\text { Frequencies, percentages, } \\
\text { normality tests, student t-test } \\
\text { for two groups, ANOVA, } \\
\text { Pearson's correlation for } \\
\text { continuous independent } \\
\text { variables. }\end{array}$ & $\begin{array}{l}\text { The knowledge about } \\
\text { palliative care needs } \\
\text { improvement especially } \\
\text { related to pain and } \\
\text { symptom management. }\end{array}$ & $5 / 5$ \\
\hline $\begin{array}{l}\text { Montagnini et } \\
\text { al. 2018, USA }\end{array}$ & $\begin{array}{l}\text { To describe health-care } \\
\text { professionals' self-perceived } \\
\text { competencies regarding the } \\
\text { provision of EOL care in } \\
\text { hospitalized patients. }\end{array}$ & Descriptive study & $\begin{array}{l}\mathrm{n}=1197 \text { health care } \\
\text { providers, including } \\
\mathrm{n}=613 \text { nurses }\end{array}$ & $\mathrm{EOL} \mathrm{Q}^{\ddagger}$ & $\begin{array}{l}\text { Means, ANOVA, } \\
\text { correlations }\end{array}$ & $\begin{array}{l}\text { Competencies among } \\
\text { health-care providers, } \\
\text { disciplines and levels of } \\
\text { care differ. EOL care } \\
\text { education is needed. }\end{array}$ & $4 / 5$ \\
\hline $\begin{array}{l}\text { Nakazawa et al. } \\
\text { 2009, Japan }\end{array}$ & $\begin{array}{l}\text { To develop and validate the } \\
\text { Palliative Care Knowledge Test } \\
\text { and to identify the factors } \\
\text { associated with palliative care } \\
\text { knowledge }\end{array}$ & Cross-sectional & $\begin{array}{l}\mathrm{N}=940 \text { registered } \\
\text { nurses from university } \\
\text { hospital and general } \\
\text { hospital, } \mathrm{n}=773\end{array}$ & $\mathrm{PCKT}^{\S \S}$ & $\begin{array}{l}\text { Percentages, kappa } \\
\text { coefficients, IRT, KR-20, } \\
\text { correlation coefficients, } \\
\text { unpaired t-test, ANOVA, } \\
\text { Pearsons product-moment } \\
\text { correlation coefficients, } \\
\text { multivariate linear } \\
\text { regression, regression } \\
\text { coefficients. }\end{array}$ & $\begin{array}{l}\text { The instrument can be } \\
\text { used to assess health care } \\
\text { providers knowledge } \\
\text { about palliative care. } \\
\text { Number of terminal care } \\
\text { patients cared was } \\
\text { associated with higher } \\
\text { total score. However over } \\
\text { all nursing experience was } \\
\text { not related to better } \\
\text { knowledge. }\end{array}$ & $5 / 5$ \\
\hline $\begin{array}{l}\text { Nakazawa et al. } \\
\text { 2017, Japan }\end{array}$ & $\begin{array}{l}\text { To determine changes in nurses } \\
\text { knowledge, difficulties and self- } \\
\text { reported practices through of the } \\
\text { results of two nationwide surveys } \\
\text { in Japan before and after } \\
\text { implementation of the Cancers } \\
\text { Control Act. }\end{array}$ & $\begin{array}{l}\text { Analysis of two } \\
\text { observational } \\
\text { studies }\end{array}$ & $\begin{array}{l}\mathrm{N}=7922 \text { nurses, } \\
\mathrm{n}=3438 \text { nurses from } \\
\text { previous study (2008) }\end{array}$ & $\mathrm{PCKT}^{\S \S}$ & $\begin{array}{l}\text { Nonpaired Student t-test, } \\
\text { multivariate linear } \\
\text { regression, Hedges g, } \\
\text { ANOVA, chi-square test. }\end{array}$ & $\begin{array}{l}\text { Japanese nurses } \\
\text { knowledge, difficulties } \\
\text { and self-reported practices } \\
\text { improved during 2008- } \\
2015 \text {. }\end{array}$ & $5 / 5$ \\
\hline
\end{tabular}




\begin{tabular}{|c|c|c|c|c|c|c|c|}
\hline $\begin{array}{l}\text { Price et. al. } \\
\text { 2017, not } \\
\text { reported }\end{array}$ & $\begin{array}{l}\text { To assess nurses' self-perceived } \\
\text { competence of knowledge, } \\
\text { attitudes and behavior about } \\
\text { palliative and EOL care. }\end{array}$ & Descriptive survey & $\begin{array}{l}\mathrm{n}=583 \text { registered nurses } \\
\text { from acute care and } \\
\text { ICU }\end{array}$ & EOL-ICU ${ }^{\mathbf{P P}}$ & $\begin{array}{l}\text { Means, one way ANOVA, } \\
\text { correlations, Cronbach's } \\
\text { alpha, theme identification, } \\
\text { grouping. }\end{array}$ & $\begin{array}{l}\text { Educational needs are } \\
\text { different according to } \\
\text { patient population and } \\
\text { acuity setting and also } \\
\text { related to demographic } \\
\text { variables of staff. }\end{array}$ & $3 / 5$ \\
\hline $\begin{array}{l}\text { Razban et al. } \\
\text { 2015, Iran }\end{array}$ & $\begin{array}{l}\text { To examine the correlation } \\
\text { between nurses' knowledge about } \\
\text { and attitude towards palliative } \\
\text { care. }\end{array}$ & $\begin{array}{l}\text { Descriptive, } \\
\text { correlational study }\end{array}$ & $\begin{array}{l}\mathrm{N}=140, \mathrm{n}=113 \\
\text { oncology and ICU } \\
\text { nurses }\end{array}$ & $\mathrm{PCQN \dagger}$ & $\begin{array}{l}\text { Descriptive statistics, } \\
\text { Pearson correlation } \\
\text { coefficient, Independent T- } \\
\text { test, ANOVA }\end{array}$ & $\begin{array}{l}\text { PCQN mean score was } \\
7.59 \pm 2.28 \text { out of } 20 . \\
\text { Participants had } \\
\text { moderately negative to } \\
\text { neutral attitudes toward } \\
\text { palliative care. } \\
\end{array}$ & $4 / 5$ \\
\hline $\begin{array}{l}\text { Sato et al. 2014, } \\
\text { Japan }\end{array}$ & $\begin{array}{l}\text { To investigate palliative care } \\
\text { knowledge, difficulty and self- } \\
\text { reported practice of nurses caring } \\
\text { cancer patients. }\end{array}$ & $\begin{array}{l}\text { Cross-sectional } \\
\text { survey }\end{array}$ & $\begin{array}{l}\mathrm{N}=3008, \mathrm{n}=2378 \\
\text { nurses working in } \\
\text { cancer-related } \\
\text { specialties }\end{array}$ & $\mathrm{PCKT}^{\S \S}$ & $\begin{array}{l}\text { Descriptive statistics, t-test, } \\
\text { ANOVA, chi-square test, } \\
\text { univariate analysis, } \\
\text { multivariate analysis }\end{array}$ & $\begin{array}{l}\text { Knowledge, difficulty and } \\
\text { self-reported practice for } \\
\text { symptom management } \\
\text { was insufficient. }\end{array}$ & $5 / 5$ \\
\hline $\begin{array}{l}\text { Schnell-Hoehn } \\
\text { et al. 2017, } \\
\text { Canada }\end{array}$ & $\begin{array}{l}\text { To explore palliative care } \\
\text { knowledge of cardiac nurses. }\end{array}$ & $\begin{array}{l}\text { Descriptive cross- } \\
\text { sectional }\end{array}$ & $\begin{array}{l}\mathrm{N}=126, \mathrm{n}=76 \text { cardiac } \\
\text { nurses }\end{array}$ & $\mathrm{PCQN} \dagger$ & $\begin{array}{l}\text { Descriptive statistics, } \\
\text { continuous variables (means, } \\
\text { sd:s), t-test to determine } \\
\text { comparisons } \\
\end{array}$ & $\begin{array}{l}\text { Mean score 15/20. } \\
\text { Knowledge gaps existed } \\
\text { in some sections of the } \\
\text { care. }\end{array}$ & $3 / 5$ \\
\hline $\begin{array}{l}\text { Shimizu et al. } \\
\text { 2016, Japan }\end{array}$ & $\begin{array}{l}\text { To develop and validate scales to } \\
\text { assess home care nurses attitude, } \\
\text { self-reported practices, difficulties } \\
\text { and knowledge regarding home } \\
\text { palliative cancer care. }\end{array}$ & $\begin{array}{l}\text { Cross-sectional } \\
\text { survey }\end{array}$ & $\begin{array}{l}\mathrm{N}=125, \mathrm{n}=122 \text { home } \\
\text { care nurses }\end{array}$ & Self-developed scales & $\begin{array}{l}\text { Descriptive statistics, } \\
\text { exploratory factor analysis, } \\
\text { Cronbach's alpha, Item } \\
\text { Response Theory (IRT), } \\
\text { multiple logistic regression } \\
\text { model, univariate analysis }\end{array}$ & $\begin{array}{l}\text { The developed scales } \\
\text { were valid and reliable to } \\
\text { evaluate home care nurses } \\
\text { attitude, self-reported } \\
\text { practices, difficulties and } \\
\text { knowledge regarding } \\
\text { home palliative cancer } \\
\text { care. Scales are useful for } \\
\text { evaluating education } \\
\text { programs. }\end{array}$ & $5 / 5$ \\
\hline $\begin{array}{l}\text { Slåtten et al. } \\
\text { 2014, Norway }\end{array}$ & $\begin{array}{l}\text { To test and validate a new } \\
\text { instrument for self-assessment for } \\
\text { core competences in palliative } \\
\text { care. }\end{array}$ & Cross-sectional & $\begin{array}{l}\mathrm{N}=235 \text { clinical nurse } \\
\text { specialists, } \mathrm{n}=122\end{array}$ & NCPC - instrument ${ }^{\text {ttt }}$ & $\begin{array}{l}\text { Cronbach's alpha (internal } \\
\text { consistency), Little's missing } \\
\text { completely at random } \\
\text { (MCAR) test, chi-square test, } \\
\text { structural equation model, } \\
\text { confirmatory factor analysis, } \\
\text { comparative fit index, } \\
\text { Tucker-Lewis fit index, root } \\
\text { mean square error of } \\
\text { approximation }\end{array}$ & $\begin{array}{l}\text { The instrument has } \\
\text { potential refining } \\
\text { competence in palliative } \\
\text { care, although it needs } \\
\text { further testing in practice. }\end{array}$ & $5 / 5$ \\
\hline
\end{tabular}

${ }^{\dagger}$ PCQN - instrument $=$ the Palliative Care Quiz for Nursing

${ }^{2}$ ELNEC-J CQ = End-of-Life Nursing Education Consortium-Japan Core Quiz

PCNSC $=$ Palliative Care Nursing Self-competence Scale

EPCS - instrument $=$ The End-of-Life Professional Caregiver Survey

"广Questionnaire on the Knowledge, Attitudes, and Behavioral Intentions of Medical personnel in Providing Artificial Nutrition and Hydration

EOL-Q = End-of-Life Questionnaire

$\$$ PCKT - instrument $=$ Palliative Care Knowledge Tes

PEOL-ICU = The Scale of End-Of-Life Care in ICU 
\#TSelf-developed scales

NCPC - instrument $=$ Nurses Core Competences in Palliative Care 
TABLE 2. The content of knowledge and skills evaluating instruments

\begin{tabular}{|c|c|c|c|}
\hline Main categories & Categories & Sub-categories & Instrument \\
\hline \multirow[t]{15}{*}{$\begin{array}{l}\text { Care for the } \\
\text { patient }\end{array}$} & \multirow[t]{2}{*}{$\begin{array}{l}\text { General basis of } \\
\text { palliative care }\end{array}$} & Principles in palliative care & $\begin{array}{l}\text { EPCS (Lazenby et al., 2012,Feder et al., 2018), Ly et al., } \\
\text { 2014, NCPC (Slåtten et al., 2014), PCNSC (Desbiens \& } \\
\text { Fillion, 2011, Ly et al., 2014), PCQN (Kim et al., 2011, } \\
\text { Choi et al., 2012, Iranmanesh et al., 2012, Autor et al., } \\
\text { 2013, Abudari et al., 2014, Kim \& Hwang, 2014, Razban } \\
\text { et al., 2015, Schnell-Hoehn et al., 2017, Chover-Sierra et } \\
\text { al., 2017a, Chover-Sierra et al., 2017b), PCKT (Nakazawa } \\
\text { et al., 2009, Sato et al., 2014, Nakazawa et al., 2017), } \\
\text { Shimizu et al. } 2016\end{array}$ \\
\hline & & $\begin{array}{l}\text { Identifying patients applicability to palliative } \\
\text { care }\end{array}$ & $\begin{array}{l}\text { EPCS (Feder et al. 2018, Lazenby et al. 2012), PCQN } \\
\text { (Kim et al., 2011, Choi et al., 2012, Iranmanesh et al., } \\
\text { 2012, Autor et al., 2013, Abudari et al., 2014, Kim \& } \\
\text { Hwang, 2014, Razban et al., 2015, Schnell-Hoehn et al., } \\
\text { 2017, Chover-Sierra et al., 2017a, Chover-Sierra et al., } \\
\text { 2017b), PCKT (Nakazawa et al., 2009, Sato et al., 2014, } \\
\text { Nakazawa et al., 2017), Shimizu et al., } 2016\end{array}$ \\
\hline & \multirow[t]{2}{*}{$\begin{array}{l}\text { Patient's } \\
\text { involvement to } \\
\text { his/her own care }\end{array}$} & Support for decision making & $\begin{array}{l}\text { ELNEC-J-QC (Arahata et al., 2018), EOL-Q (Montagnini } \\
\text { et al., 2018), EOL-ICU (Price et. al. ,2017), PCNSC } \\
\text { (Desbiens \& Fillion, 2011, Ly et al., 2014) }\end{array}$ \\
\hline & & Support for management in daily life & PCNSC (Desbiens \& Fillion, 2011, Ly et al., 2014) \\
\hline & \multirow[t]{2}{*}{$\begin{array}{l}\text { Psychosocial } \\
\text { support }\end{array}$} & Identifying patient's psychical needs & $\begin{array}{l}\text { EOL-Q (Montagnini et al. 2018), EOL-ICU (Price et. al. } \\
\text { 2017), PCNSC (Desbiens \& Fillion 2011, Ly et al. 2014), } \\
\text { PCQN (Kim et al., 2011, Choi et al., 2012, Iranmanesh et } \\
\text { al., 2012, Autor et al., 2013, Abudari et al., 2014, Kim \& } \\
\text { Hwang, 2014, Razban et al., 2015, Schnell-Hoehn et al., } \\
\text { 2017, Chover-Sierra et al., 2017a, Chover-Sierra et al., } \\
\text { 2017b) }\end{array}$ \\
\hline & & Supporting coping with life-limiting illness & $\begin{array}{l}\text { EOL-Q (Montagnini et al., 2018), EOL-ICU (Price et. al., } \\
\text { 2017), PCNSC (Desbiens \& Fillion, 2011, Ly et al., 2014) }\end{array}$ \\
\hline & \multirow[t]{2}{*}{ Spiritual support } & Assess and recognize patients spiritual needs & $\begin{array}{l}\text { EOL-Q (Montagnini et al., 2018), EOL-ICU (Price et. al., } \\
\text { 2017), PCNSC (Desbiens \& Fillion, 2011, Ly et al., 2014) }\end{array}$ \\
\hline & & $\begin{array}{l}\text { Dealing with spiritual perspectives of the } \\
\text { patient }\end{array}$ & $\begin{array}{l}\text { EPCS (Feder et al. ,2018, Lazenby et al., 2012), Ly et al., } \\
\text { 2014, PCNSC (Desbiens \& Fillion, 2011, Ly et al., 2014) }\end{array}$ \\
\hline & \multirow[t]{2}{*}{$\begin{array}{l}\text { Cultural aspects in } \\
\text { care }\end{array}$} & Identifying cultural aspects & $\begin{array}{l}\text { EPCS (Feder et al., 2018, Lazenby et al., 2012), EOL-Q } \\
\text { (Montagnini et al., 2018), EOL-ICU (Price et. al., 2017) }\end{array}$ \\
\hline & & Operating with cultural aspects & $\begin{array}{l}\text { EPCS (Feder et al., 2018, Lazenby et al., 2012), PCNSC } \\
\text { (Desbiens \& Fillion, 2011, Ly et al., 2014) }\end{array}$ \\
\hline & \multirow[t]{2}{*}{$\begin{array}{l}\text { Pharmacological } \\
\text { treatment }\end{array}$} & Efficacy of drugs and medication & $\begin{array}{l}\text { PCQN (Kim et al., 2011, Choi et al., 2012, Iranmanesh et } \\
\text { al., 2012, Autor et al., 2013, Abudari et al., 2014, Kim \& } \\
\text { Hwang, 2014, Razban et al., 2015, Schnell-Hoehn et al., } \\
\text { 2017, Chover-Sierra et al., 2017a, Chover-Sierra et al., } \\
\text { 2017b), PCKT (Nakazawa et al. 2009, Sato et al. 2014, } \\
\text { Nakazawa et al. 2017), Shimizu et al. } 2016\end{array}$ \\
\hline & & Knowledge about side-effects & $\begin{array}{l}\text { PCQN (Kim et al., 2011, Choi et al., 2012, Iranmanesh et } \\
\text { al., 2012, Autor et al., 2013, Abudari et al., 2014, Kim \& } \\
\text { Hwang, 2014, Razban et al., 2015, Schnell-Hoehn et al., } \\
\text { 2017, Chover-Sierra et al., 2017a, Chover-Sierra et al., } \\
\text { 2017b), PCKT (Nakazawa et al., 2009, , Sato et al., 2014, } \\
\text { Nakazawa et al., 2017), PCNSC (Desbiens \& Fillion, } \\
\text { 2011, Ly et al., 2014), Shimizu et al., 2016 }\end{array}$ \\
\hline & \multirow[t]{3}{*}{$\begin{array}{l}\text { Physical symptom } \\
\text { management }\end{array}$} & Respiratory symptom management & $\begin{array}{l}\text { EOL-Q (Montagnini et al., 2018), EOL-ICU (Price et al., } \\
\text { 2017), PCNSC (Desbiens \& Fillion, 2011, Ly et al., } \\
\text { 2014), PCKT (Nakazawa et al., 2009, , Sato et al., 2014, } \\
\text { Nakazawa et al., 2017), Shimizu et al., } 2016\end{array}$ \\
\hline & & Gastro-intestinal symptom management & $\begin{array}{l}\text { EOL-Q (Montagnini et al., 2018), EOL-ICU (Price et al., } \\
\text { 2017), NCPC (Slåtten et al., 2014), PCNSC (Desbiens \& } \\
\text { Fillion, 2011, Ly et al., 2014) }\end{array}$ \\
\hline & & Pain evaluation & $\begin{array}{l}\text { PCQN (Kim et al., 2011, Choi et al., 2012, Iranmanesh et } \\
\text { al., 2012, Autor et al., 2013, Abudari et al., 2014, Kim \& } \\
\text { Hwang, 2014, Razban et al., 2015, Schnell-Hoehn et al., } \\
\text { 2017, Chover-Sierra et al., 2017a, Chover-Sierra et al., } \\
\text { 2017b), PCKT (Nakazawa et al., 2009, , Sato et al., 2014, } \\
\text { Nakazawa et al. ,2017), PCNSC (Desbiens \& Fillion, } \\
\text { 2011, Ly et al., 2014), Shimizu et al., 2016 }\end{array}$ \\
\hline
\end{tabular}




\begin{tabular}{|c|c|c|c|}
\hline & & Pain management & $\begin{array}{l}\text { EOL-Q (Montagnini et al., 2018), EOL-ICU (Price et. al., } \\
\text { 2017), PCNSC (Desbiens \& Fillion, 2011, Ly et al. } \\
\text {,2014), PCKT (Nakazawa et al., 2009, , Sato et al., 2014, } \\
\text { Nakazawa et al., 2017), PCQN (Kim et al., 2011, Choi et } \\
\text { al., 2012, Iranmanesh et al., 2012, Autor et al., 2013, } \\
\text { Abudari et al., 2014, Kim \& Hwang, 2014, Razban et al., } \\
\text { 2015, Schnell-Hoehn et al., 2017, Chover-Sierra et al., } \\
\text { 2017a, Chover-Sierra et al., 2017b) }\end{array}$ \\
\hline & \multirow[t]{3}{*}{ End-of-life care } & Symptoms and signs of approaching death & $\begin{array}{l}\text { PCNSC (Desbiens \& Fillion, 2011, Ly et al., 2014), } \\
\text { Shimizu et al., } 2016\end{array}$ \\
\hline & & $\begin{array}{l}\text { Identifying physical needs and symptom } \\
\text { management }\end{array}$ & $\begin{array}{l}\text { PCQN (Kim et al., 2011, Choi et al., 2012, Iranmanesh et } \\
\text { al., 2012, Autor et al., 2013, Abudari et al., 2014, Kim \& } \\
\text { Hwang, 2014, Razban et al., 2015, Schnell-Hoehn et al., } \\
\text { 2017, Chover-Sierra et al., 2017a, Chover-Sierra et al., } \\
\text { 2017b), PCKT (Nakazawa et al., 2009, , Sato et al., 2014, } \\
\text { Nakazawa et al., 2017), PCNSC (Desbiens \& Fillion, } \\
\text { 2011, Ly et al., 2014), Shimizu et al. 2016, Questionnaire } \\
\text { on the Knowledge, Attitudes, and Behavioral Intentions of } \\
\text { Medical personnel in Providing Artificial Nutrition and } \\
\text { Hydration (Ke et al., 2008) }\end{array}$ \\
\hline & & Emotional support & PCNSC (Desbiens \& Fillion, 2011, Ly et al., 2014) \\
\hline \multirow[t]{9}{*}{$\begin{array}{l}\text { Care for the } \\
\text { family }\end{array}$} & \multirow{2}{*}{$\begin{array}{l}\text { Involving family } \\
\text { to the care of the } \\
\text { patient }\end{array}$} & Family's involvement to the care planning & $\begin{array}{l}\text { EOL-Q (Montagnini et al. ,2018), EOL-ICU (Price et. al., } \\
\text { 2017), PCNSC (Desbiens \& Fillion, 2011, Ly et al., 2014) }\end{array}$ \\
\hline & & Family's involvement to the care & $\begin{array}{l}\text { EPCS (Lazenby et al., 2012, Feder et al., 2018), Ly et al., } \\
\text { 2014, PCNSC (Desbiens \& Fillion, 2011, Ly et al., 2014) }\end{array}$ \\
\hline & \multirow[t]{3}{*}{$\begin{array}{l}\text { Psychosocial } \\
\text { support }\end{array}$} & Identifying family's psychical needs & $\begin{array}{l}\text { EOL-Q (Montagnini et al. 2018), EOL-ICU (Price et al., } \\
\text { 2017), PCNSC (Desbiens \& Fillion, 2011, Ly et al., 2014) }\end{array}$ \\
\hline & & Supporting coping with patient's illness & $\begin{array}{l}\text { EOL-Q (Montagnini et al., 2018), EOL-ICU (Price et al., } \\
\text { 2017), EPCS (Feder et al., 2018, Lazenby et al. ,2012), Ly } \\
\text { et al., 2014, PCNSC (Desbiens \& Fillion, 2011, Ly et al., } \\
\text { 2014) }\end{array}$ \\
\hline & & Support in undergoing death & $\begin{array}{l}\text { PCQN (Kim et al., 2011, Choi et al., 2012, Iranmanesh et } \\
\text { al., 2012, Autor et al., 2013, Abudari et al., 2014, Kim \& } \\
\text { Hwang, 2014, Razban et al., 2015, Schnell-Hoehn et al., } \\
\text { 2017, Chover-Sierra et al., 2017a, Chover-Sierra et al., } \\
\text { 2017b), PCNSC (Desbiens \& Fillion, 2011, Ly et al., } \\
\text { 2014) }\end{array}$ \\
\hline & \multirow[t]{2}{*}{ Spirituality } & $\begin{array}{l}\text { Assess and recognize family members spiritual } \\
\text { needs }\end{array}$ & $\begin{array}{l}\text { EOL-Q (Montagnini et al., 2018), EOL-ICU (Price et al., } \\
\text { 2017), PCNSC (Desbiens \& Fillion, 2011, Ly et al., 2014) }\end{array}$ \\
\hline & & $\begin{array}{l}\text { Dealing with spiritual perspectives of the } \\
\text { family }\end{array}$ & $\begin{array}{l}\text { EPCS (Lazenby et al., 2012, Feder et al., 2018), PCNSC } \\
\text { (Desbiens \& Fillion, 2011, Ly et al., 2014) }\end{array}$ \\
\hline & \multirow[t]{2}{*}{$\begin{array}{l}\text { Cultural aspects in } \\
\text { care }\end{array}$} & Identifying cultural aspects & $\begin{array}{l}\text { EPCS (Lazenby et al., 2012, Feder et al., 2018), EOL-Q } \\
\text { (Montagnini et al., 2018), EOL-ICU (Price et al., 2017) }\end{array}$ \\
\hline & & Operating with cultural aspects & $\begin{array}{l}\text { EPCS (Feder et al., 2018, Lazenby et al., 2012), PCNSC } \\
\text { (Desbiens \& Fillion, 2011, Ly et al., 2014) }\end{array}$ \\
\hline \multirow[t]{8}{*}{$\begin{array}{l}\text { Professional } \\
\text { requirements }\end{array}$} & \multirow[t]{2}{*}{ Ethicalness } & Identifying ethical issues & $\begin{array}{l}\text { ELNEC-J-QC (Arahata et al., 2018), NCPC (Slåtten et al., } \\
\text { 2014), PCNSC (Desbiens \& Fillion, 2011, Ly et al., 2014) }\end{array}$ \\
\hline & & Operating with ethical issues & PCNSC (Desbiens \& Fillion, 2011, Ly et al., 2014) \\
\hline & \multirow[t]{2}{*}{ Coping with death } & Preparedness for death & $\begin{array}{l}\text { ELNEC-J-QC (Arahata et al., 2018), EOL-Q (Montagnini } \\
\text { et al., 2018), EOL-ICU (Price et al., 2017), NCPC (Slåtten } \\
\text { et al., 2014) }\end{array}$ \\
\hline & & Adaptation for dying & PCNSC (Desbiens \& Fillion ,2011, Ly et al., 2014) \\
\hline & \multirow{2}{*}{$\begin{array}{l}\text { Collaboration } \\
\text { skills }\end{array}$} & Interpersonal collaboration & NCPC (Slåtten et al. ,2014) \\
\hline & & Multi-professional collaboration & $\begin{array}{l}\text { EPCS (Lazenby et al., 2012,Feder et al., 2018), NCPC } \\
\text { (Slåtten et al., 2014), PCNSC (Desbiens \& Fillion, 2011, } \\
\text { Ly et al., 2014) }\end{array}$ \\
\hline & \multirow[t]{2}{*}{ Personal resources } & Identifying own resources and needs & $\begin{array}{l}\text { EPCS (Lazenby et al., 2012, Feder et al., 2018), PCQN } \\
\text { (Kim et al., 2011, Choi et al., 2012, Iranmanesh et al., } \\
\text { 2012, Autor et al., 2013, Abudari et al., 2014, Kim \& } \\
\text { Hwang, 2014, Razban et al., 2015, Schnell-Hoehn et al., } \\
\text { 2017, Chover-Sierra et al., 2017a, Chover-Sierra et al., } \\
\text { 2017b), PCNSC (Desbiens \& Fillion, 2011, Ly et al., } \\
\text { 2014) }\end{array}$ \\
\hline & & Support from workplace & EPCS (Lazenby et al., 2012, Feder et al., 2018) \\
\hline
\end{tabular}


TABLE 3. Description of the palliative care competence instruments

\begin{tabular}{|c|c|c|c|c|c|c|c|}
\hline & $\begin{array}{l}\text { Instrument/ } \\
\text { developer }\end{array}$ & Source & $\begin{array}{l}\text { Aim of the } \\
\text { instrument }\end{array}$ & Items $^{\dagger}$ & $\begin{array}{l}\text { Knowledge / } \\
\text { self-evaluation } \\
\text { instrument }\end{array}$ & Subscales/ contents & Validity and reliability of the instrument \\
\hline 1 & $\begin{array}{l}\text { PCQN (the Palliative } \\
\text { Care Quiz for } \\
\text { Nursing), } \\
\text { Ross et al. } 1996\end{array}$ & $\begin{array}{l}\text { Abudari et al. 2014, Autor } \\
\text { et al. 2013, Choi et al. } \\
\text { 2012, Chover-Sierra et al. } \\
\text { 2017a, Chover-Sierra et } \\
\text { al. 2017b, Iranmanesh et } \\
\text { al. 2012, Kim \& Hwang } \\
\text { 2014, Kim et al. 2011, } \\
\text { Razban et al. 2015, } \\
\text { Schnell-Hoehn et al. } 2017\end{array}$ & $\begin{array}{l}\text { To quantify } \\
\text { knowledge } \\
\text { regarding } \\
\text { palliative care. }\end{array}$ & $\begin{array}{l}20 \text { questions with true, } \\
\text { false, I do not know. }\end{array}$ & Knowledge & $\begin{array}{l}\text { Understanding of philosophy, principles of PC, pain, } \\
\text { symptom, management, psychosocial care. }\end{array}$ & $\begin{array}{l}\text { Test-retest } 0,56, \text { KR-20 } 0,65-0,78, \text { item } \\
\text { discrimination index greater than } 0,50, \\
\text { Cronbach's alpha } 0,67 \text {, Content validity } \\
\text { index } 0,76-0,85, \text { IRT } 0,19-0,97 \text {. } \\
\text { Acceptable reliability and validity reported in } \\
\text { current and previous studies. }\end{array}$ \\
\hline 2 & $\begin{array}{l}\text { ELNEC-J CQ (End- } \\
\text { of-Life Nursing } \\
\text { Education } \\
\text { Consortium-Japan } \\
\text { Core Quiz), Arahata } \\
\text { et al. } 2018\end{array}$ & Arahata et al. 2018 & $\begin{array}{l}\text { To assess } \\
\text { knowledge and } \\
\text { attitude } \\
\text { improvement } \\
\text { toward } \\
\text { palliative and } \\
\text { EOL care. }\end{array}$ & $\begin{array}{l}90 \text { items in } 9 \text { domains } \\
\text { about knowledge (right, } \\
\text { wrong, unsure) and } 10 \\
\text { items in } 3 \text { domains } \\
\text { about attitudes (5-point } \\
\text { Likert scale from } \\
\text { strongly disagree to } \\
\text { strongly agree). }\end{array}$ & Knowledge & $\begin{array}{l}\text { Knowledge: Nursing care at the end of life, pain } \\
\text { management, symptom management, ethical issues in } \\
\text { EOL care, cultural considerations in EOL care, } \\
\text { communication, loss, griev, bereavement, preparation } \\
\text { for and care at the time of death, EOL care for elderly. } \\
\text { Attitude: Confidence in providing quality EOL care, } \\
\text { ability to implement interventions to improve EOL care, } \\
\text { motivations to provide quality EOL care. }\end{array}$ & $\begin{array}{l}\text { Internal consistency sufficient: KR-20 of all } \\
\text { knowledge items } 0,85 \text {, uneven result for } \\
\text { knowledge domains KR-20 0,57-0,76. } \\
\text { Reliability sufficient: ICC range for all } \\
\text { knowledge items } 0,84 \text {. }\end{array}$ \\
\hline 3 & $\begin{array}{l}\text { PCNSC }=\text { Palliative } \\
\text { Care Nursing Self } \\
\text { Competence scale, } \\
\text { Desbiens \& Fillion } \\
2011\end{array}$ & $\begin{array}{l}\text { Desbiens \& Fillion 2011, } \\
\text { Ly et al. } 2014\end{array}$ & $\begin{array}{l}\text { To evaluate } \\
\text { nurses self- } \\
\text { perceived } \\
\text { competence. }\end{array}$ & $\begin{array}{l}10 \text { items with } 1-6 \text { rated } \\
\text { strength of self- } \\
\text { competence (not at all } \\
\text { competent to highly } \\
\text { competent). }\end{array}$ & Self-evaluation & $\begin{array}{l}\text { Pain management, other symptoms management, } \\
\text { psychological care, social care, spiritual care, care } \\
\text { associated with functional status, ethical and legal } \\
\text { issues, interprofessional collaboration and } \\
\text { communication, personal and professional issues related } \\
\text { to nursing care, end-of-life care. }\end{array}$ & $\begin{array}{l}\text { Cronbach's alpha } 0,97 \text {, content validity index } \\
0,95 \text {. }\end{array}$ \\
\hline 4 & $\begin{array}{l}\text { EPCS - instrument } \\
\text { (The End-of-Life } \\
\text { Professional } \\
\text { Caregiver Survey) } \\
\text { Lazenby et al. } 2012\end{array}$ & $\begin{array}{l}\text { Feder et al. 2018, } \\
\text { Lazenby et al. } 2012\end{array}$ & $\begin{array}{l}\text { To assess core } \\
\text { competencies } \\
\text { in palliative } \\
\text { care }\end{array}$ & $\begin{array}{l}28 \text { items to assess } \\
\text { competencies with 5- } \\
\text { point Likert scale. }\end{array}$ & Self-evaluation & $\begin{array}{l}\text { Patient and Family-Centered Communication, Cultural } \\
\text { and Ethical Values, Effective Care Delivery. }\end{array}$ & $\begin{array}{l}\text { Cronbach's alpha } 0,96 \text { for all items, PFCC } \\
\text { (Cronbach's alpha } 0,95 \text {, Eigenvalue } 1, .0, \\
\text { inter-item correlations } 0,37-0,50 \text { ), CEV } \\
\text { (Cronbach's alpha } 0,89 \text {, Eigenvalue } 1,7, \\
\text { inter-item correlations } 0,55-0,75 \text { ) and ECD } \\
\text { (Cronbach's alpha } 0,87, \text { Eigenvalue } 1,1, \\
\text { inter-item correlations } 0,52-0,74 \text { ). } \\
\text { Correlations among three factors and the } \\
\text { overall EPCS } 0,80-0,92 \text {. Scale exhibits strong } \\
\text { internal reliability }\end{array}$ \\
\hline 5 & $\begin{array}{l}\text { Questionnaire on the } \\
\text { Knowledge, Attitudes, } \\
\text { and Behavioral } \\
\text { Intentions of Medical } \\
\text { personnel in } \\
\text { Providing Artificial } \\
\text { Nutrition and } \\
\text { Hydration, Ke et al. } \\
2008\end{array}$ & Ke et al. 2008 & $\begin{array}{l}\text { To assess } \\
\text { knowledge, } \\
\text { attitudes and } \\
\text { behavioral } \\
\text { intentions in } \\
\text { providing } \\
\text { ANH. }\end{array}$ & $\begin{array}{l}7 \text { part questionnaire, } 17 \\
\text { items for knowledge } \\
\text { (true and } \\
\text { false/unknown), } \\
\text { attitudes 5-point Likert } \\
\text { scale (strongly } \\
\text { disagree/unimportant to } \\
\text { strongly agree/very } \\
\text { important). }\end{array}$ & Knowledge & $\begin{array}{l}\text { Demographic characteristics, knowledge of palliative } \\
\text { care, knowledge of provision of ANH for terminal } \\
\text { cancer patients, attitudes, behavioral intentions, } \\
\text { subjective norms, influencing factors. }\end{array}$ & $\begin{array}{l}\text { Content validity index } 0,93, \mathrm{KR}-200,68 \text { to } \\
0,80 \text { in different items. }\end{array}$ \\
\hline
\end{tabular}




\begin{tabular}{|c|c|c|c|c|c|c|c|}
\hline 6 & $\begin{array}{l}\text { EOL-Q = End-of-Life } \\
\text { Questionnaire, } \\
\text { Montagnini et al. } \\
2018 \text { (original EOL- } \\
\text { Q-ICU, Montagnini et } \\
\text { al. 2012) }\end{array}$ & Montagnini et al. 2018 & $\begin{array}{l}\text { To assess self- } \\
\text { perceived } \\
\text { confidence in } \\
\text { providing end- } \\
\text { of-life care. }\end{array}$ & $\begin{array}{l}28 \text { items, 5-point } \\
\text { Likert-type scale } \\
\text { (strongly disagree to } \\
\text { strongly agree, } \\
\text { including option "not } \\
\text { acceptable"). }\end{array}$ & Self-evaluation & $\begin{array}{l}\text { Patient and family decision making, communication } \\
\text { within the team, patients and families, continuity of } \\
\text { care, emotional support for patients and families, } \\
\text { symptom management, spiritual support for patients } \\
\text { and families, emotional and organizational support for } \\
\text { staff. }\end{array}$ & $\begin{array}{l}\text { Cronbach's alpha } 0,92 \text { total. Internal } \\
\text { consistency reliability reported high in } \\
\text { previous study. }\end{array}$ \\
\hline 7 & $\begin{array}{l}\text { PCKT }- \text { instrument }= \\
\text { Palliative Care } \\
\text { Knowledge Test, } \\
\text { Nakazawa et al. } 2009\end{array}$ & $\begin{array}{l}\text { Nakazawa et al. 2009, } \\
\text { Nakazawa et al. 2017, } \\
\text { Sato et al. } 2014\end{array}$ & $\begin{array}{l}\text { To identify the } \\
\text { factors } \\
\text { associated } \\
\text { with palliative } \\
\text { care } \\
\text { knowledge. }\end{array}$ & $\begin{array}{l}40 \text { items with right, } \\
\text { wrong, unsure. }\end{array}$ & Knowledge & $\begin{array}{l}\text { Philosophy, pain, dyspnea, delirium, gastrointestinal } \\
\text { symptoms. }\end{array}$ & $\begin{array}{l}\text { ICC } 0,88 \text { overall and } 0,61-0,82 \text { in each } \\
\text { domain, KR-20 0,81, test-retest kappa } \\
\text { coefficient } 0,26-0,74 \text {,validity assessed by } \\
\text { expert discussions and IRT difficulty }-2,9 \text { - } \\
3,09 \text {, discrimination } 0,33-2,25 \text {. } \\
\text { Good internal consistency, test-retest } \\
\text { reliability, face validity and known-group } \\
\text { validity. }\end{array}$ \\
\hline 8 & $\begin{array}{l}\text { EOL-ICU }=\text { The Scale } \\
\text { of End-Of-Life Care } \\
\text { in ICU, Montagnini et } \\
\text { al. } 2012\end{array}$ & Price et. al. 2017 & $\begin{array}{l}\text { To assess self- } \\
\text { perceived } \\
\text { confidence in } \\
\text { providing EOL } \\
\text { care in the } \\
\text { ICU setting. } \\
\end{array}$ & $\begin{array}{l}28 \text { items, 5-point } \\
\text { Likert-type scale } \\
\text { (strongly disagree to } \\
\text { strongly agree, } \\
\text { including option "not } \\
\text { acceptable"). }\end{array}$ & Self-evaluation & $\begin{array}{l}\text { Decision making, communication, continuity of care, } \\
\text { emotional support for patients and families, symptom } \\
\text { management, spiritual support for patients and families } \\
\text { and emotional support for staff. }\end{array}$ & Cronbach's alphas 0,69-0,93. \\
\hline 9 & Self-developed scales & Shimizu et al. 2016 & $\begin{array}{l}\text { To evaluate } \\
\text { home care } \\
\text { nurses } \\
\text { attitudes } \\
\text { towards } \\
\text { terminal home } \\
\text { care, self- } \\
\text { reported } \\
\text { practices in } \\
\text { home } \\
\text { palliative } \\
\text { cancer care, } \\
\text { difficulties } \\
\text { experienced in } \\
\text { providing } \\
\text { home } \\
\text { palliative } \\
\text { cancer care } \\
\text { and knowledge } \\
\text { of home } \\
\text { palliative } \\
\text { cancer care. }\end{array}$ & $\begin{array}{l}\text { Knowledge } 31 \text { items } \\
\text { (true, false), attitude } 12 \\
\text { items, self-reported } \\
\text { practices } 26 \text { items, } \\
\text { difficulties } 18 \text { items all } \\
\text { with 5-point Likert } \\
\text { scale. }\end{array}$ & Knowledge & $\begin{array}{l}\text { Symptom palliation, regional cooperation, } \\
\text { communication with medical practitioners, philosophy, } \\
\text { pain and opioids, dyspnea, psychiatric problems, } \\
\text { gastrointestinal problems, dying care. } \\
\text { Confidence in staff support, confidence in } \\
\text { communication with physicians, willingness to provide } \\
\text { home palliative cancer care, confidence in home } \\
\text { palliative cancer care, family care, coordination with } \\
\text { care manager/care person, patient- and family-centered } \\
\text { care, pain management, respect for the } \\
\text { patient's/family's preferences for place of care, } \\
\text { coordination with family/hospital physicians, dying care } \\
\text { and family care, communication with patient and } \\
\text { family, }\end{array}$ & $\begin{array}{l}\text { Cronbach's alphas } 0,61-0,70, \text { IRT difficulty } \\
-3,24-1,05 \text {, discrimination } 0,56-3,06 \text {. } \\
\text { Construct validity good and internal } \\
\text { consistency satisfactory. }\end{array}$ \\
\hline 10 & $\begin{array}{l}\text { NCPC }- \text { instrument }= \\
\text { Nurses Core } \\
\text { Competences in } \\
\text { Palliative Care }\end{array}$ & Slåtten et al. 2014 & $\begin{array}{l}\text { To evaluate } \\
\text { nurses' core } \\
\text { competencies } \\
\text { in palliative } \\
\text { care. }\end{array}$ & $\begin{array}{l}26 \text { questions rated with } \\
\text { 5-point Likert scale (I } \\
\text { don't agree at all to } \\
\text { agree completely }\end{array}$ & Self-evaluation & $\begin{array}{l}\text { Knowledge and Symptom Management, Systematic } \\
\text { Use of the Edmonton Symptom Assessment System } \\
\text { (ESAS), Teamwork Skills, Interpersonal Skills, Life } \\
\text { Closure Skills. }\end{array}$ & $\begin{array}{l}\text { Cronbach's alphas } 0,51-0,97 \text { in different } \\
\text { items, Chi-square } 368 \text { (d.f. }=283, \mathrm{n}=122, \mathrm{P}< \\
0,05 \text { ). CFI } 0,95 \text {, TLI 0,95, RMSEA } 0,05 \text { (Lo } \\
90=0,26 \text { and HI } 90=0,06 \text { ). The construct } \\
\text { validity having acceptable factor loading }\end{array}$ \\
\hline
\end{tabular}




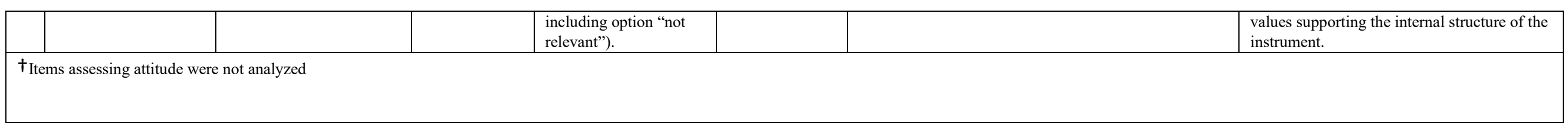

\section{Figure legends:}

FIGURE 1. Retrieval of the studies (PRISMA)

From: Moher, .D, Liberati, A., Tetzlaff, J., Altman, D. G., The PRISMA Group (2009). Preferred Reporting Items for Systematic Reviews and Meta-Analyses: The PRISMA Statement. PLoS Med 6(6): e1000097.

doi:10.1371/journal.pmed1000097) 


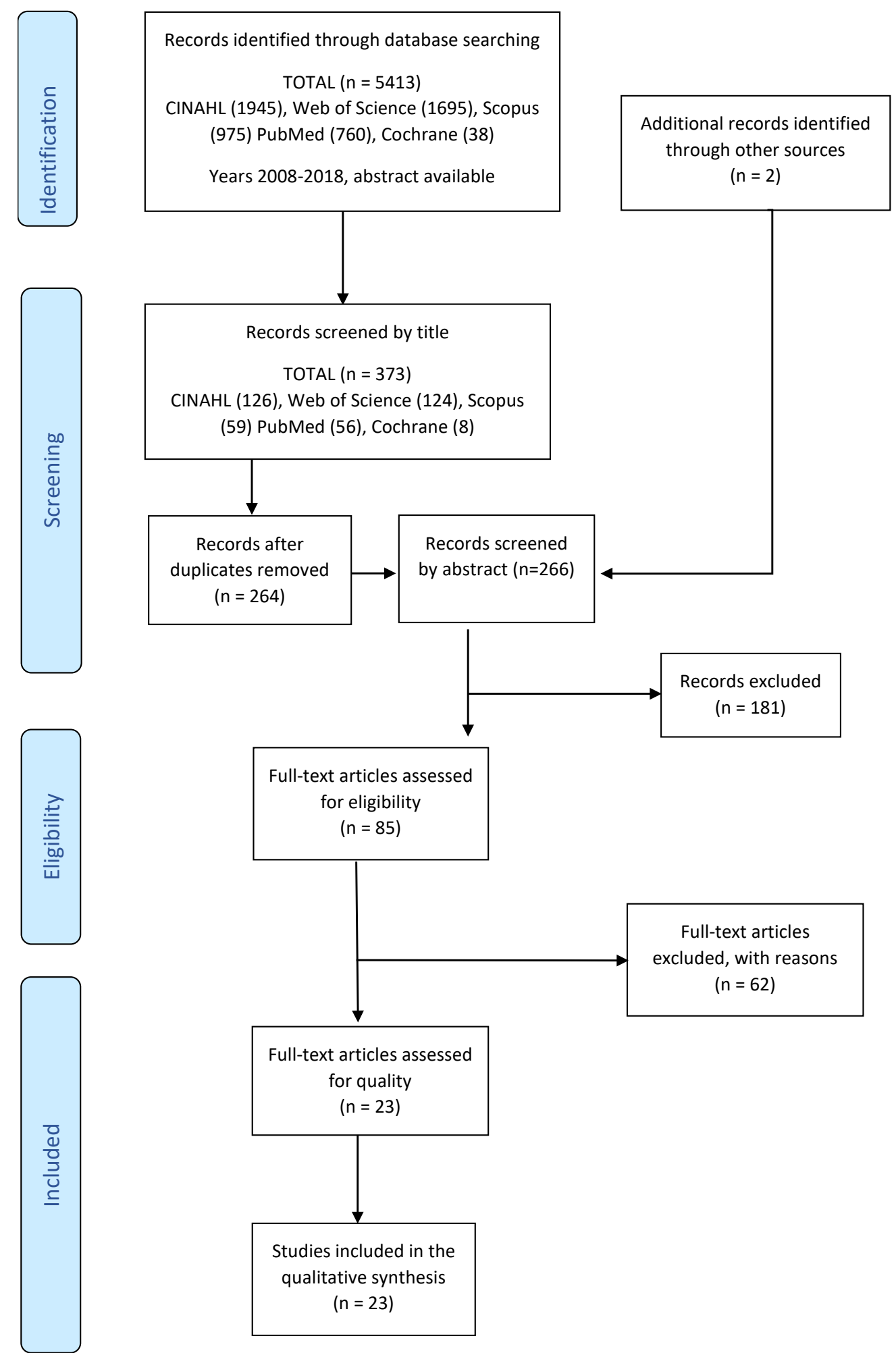

